\title{
Production of Egg Yolk Immunoglobulin (IgY) Against Recombinant LTB of Enterotoxigenic Escherichia coli (ETEC) and Evaluation of Its Protective Effect in Animal Model
}

Maryam Mafi ${ }^{1}$, Seyed Latif Mousavi Gargari ${ }^{2}$, Shahram Nazarian ${ }^{3}$, Tatemeh.Mohammad khani $^{4}$ 1-Ms.C Microbial Biotechnology, Departmant of Cell Biology, Faculty of Basic Sciences, Shahed University, Tehran, Iran. ORCID ID:0000-0002-8442-020X

2-Ph.D Biochemistry Departmant of Cell Biology, Faculty of Basic Sciences, Shahed University, Tehran, Iran. (Corresponding Author), Tel:021-51212232, Email:slmousavi@ shahed.ac.ir. ORCID ID:0000-0002-4635-8716

3-Ph.D Microbiology, Biology Research Centere, Basic Science Faculty, Imam Hossein University, Tehran, Iran.ORCID ID:0000-0002-4693-877X

4- Ms.C Microbial Biotechnology, Departmant of Cell Biology, Faculty of Basic Sciences, Shahed University, Tehran, Iran. ORCID ID:0000-0002-8802-471X

\begin{abstract}
Background and Aim: Enterotoxigenic Escherichia coli is one of the most common bacterial causes of diarrhea worldwide. One of the most important ETEC colonization factors is B subunit of the heat labile enterotoxin, which forms the connecting part of the toxin. In the present study, egg yolk immunoglobulin (IgY) against recombinant LTB protein was produced and its protective effect was evalutated in the animal model.

Material and methods: Hens were injected intramuscularly with $100 \mu \mathrm{g}$ of recombinant LTB protein. Antibody titers of the sera were estimated and the eggs were collected. IgYs were purified from egg yolk and the antibody titers were subsequently estimated by ELISA method. Effecacy of different concentrations of IgY against the effect of LT toxin on Y1 cells was also studied. In order to investigate the effect of IgY-treated bacteria on intestinal epithelial cells we used standard Ileal loop technique.
\end{abstract}

Results: Induction of protein expression led to the production of recombinant LTB with molecular weight of about $14 \mathrm{kDa}$. Concentration of purified protein was $4.5 \mathrm{mg} / \mathrm{ml}$. Immunization of the hens induced serum antibody rise. IgY against LTB was purified from egg yolk at a concentration of $12 \mathrm{mg} / \mathrm{ml} .125 \mu \mathrm{g}$ per $\mathrm{ml}$ of IgY against LTB prevented the effects of heat labile enterotoxin on Y1. In the Ileal loop test, $1.5 \mathrm{mg} / \mathrm{ml}$ of $\mathrm{IgY}$ neutralized the toxin effect of LTB on the intestine. Accumulation of fluid in the test loops decreased by $74.8 \%$ compared to that in the untreated control loops.

Conclusion: The results obtained indicated that specific egg yolk immunoglobulin was effective against recombinant LTB protein and can be used as a preventive antibody to inhibit the heat labile enterotoxin function of ETEC bacteria.

Keywords: Enterotoxigenic Escherichia coli, Heat labile enterotoxin, Passive immunity, Egg yolk immunoglobulin, Virulance factor

Received: April 20, 2020

Accepted: Jan 11, 2021

How to cite the article: M.Mafi,S.L.Mousavi Gargari-,Sh.Nazarian ,F.Mohammad khani. Production of Egg

Yolk Immunoglobulin (IgY) Against Recombinant LTB of Enterotoxigenic Escherichia coli (ETEC) and Evaluation of Its Protective Effect in Animal Model.IُĆSJKU2021;26(6):107-123.

Copyright $@ 2018$ the Author (s). Published by Kurdistan University of Medical Sciences. This is an open access article distributed under the terms of the Creative Commons Attribution-Non Commercial License 4.0 (CCBYNC), where it is permissible to download, share, remix, transform, and buildup the work provided it is properly cited. The work cannot be used commercially without permission from the journal 


\section{توليد ايمونو تلوبولين مرغى (IgY) عليه يروتئين نوتر كيب LTB از اشرشياكلى

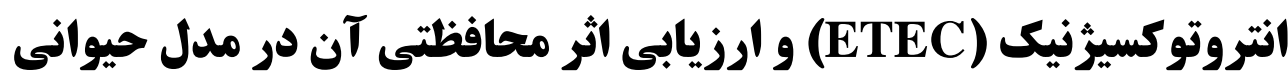

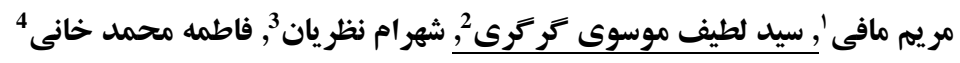

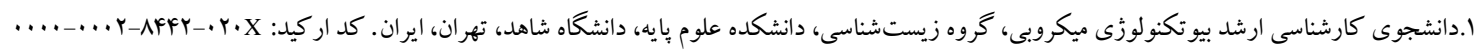

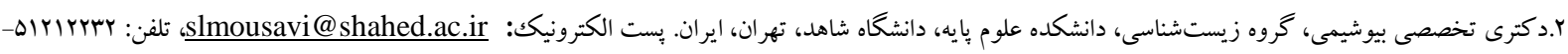
........r-rqra-AVI9

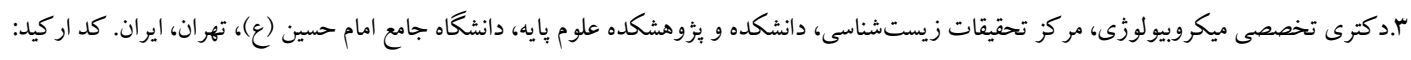
...._...r-r999-AVVX

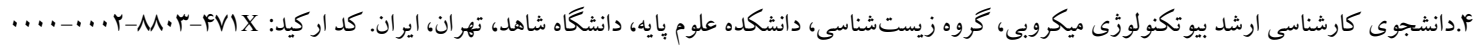

زمينه و هدف: اشــــــاكلى انتروتو كسـيزنيكك يكى از رايجترين عوامل باكتريايى مولد اســهال در جهان اســت. از مهم ترين فاكتورهاى حدتزا Enterotoxigenic Escherichia coli

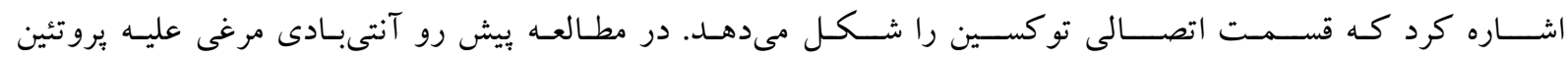

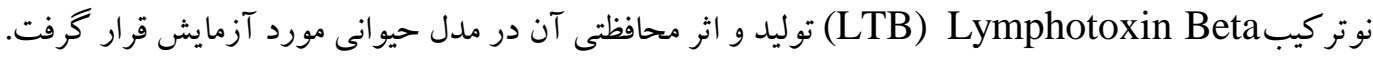
مواد و روشها: .. اميكروكرم يروتئين نوتركيب LTB به صورت داخل عضلانى به مرغها تزريق شد. تيتر آنتىبادى در سرم

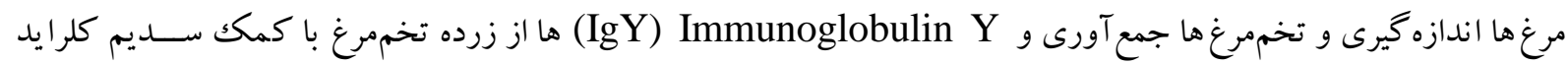

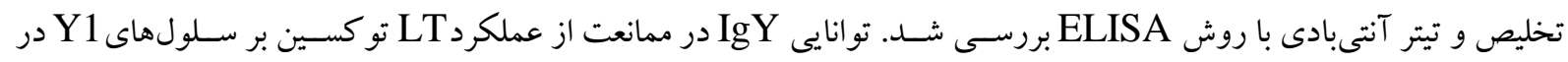

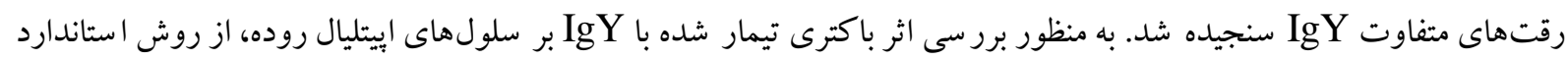
لو لوب ايلئال استفاده گرديد.

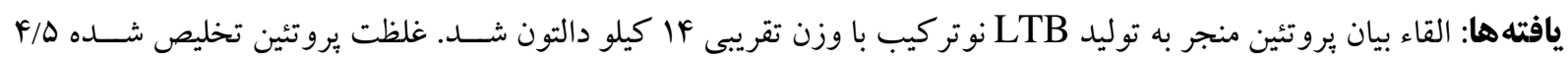

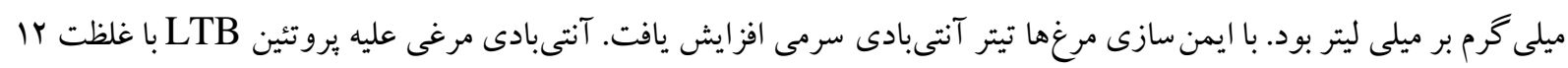

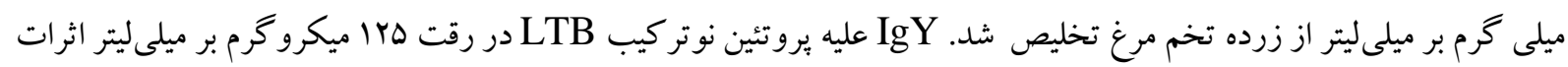

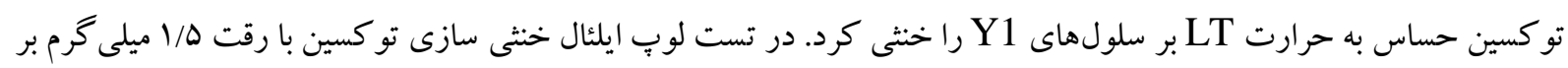

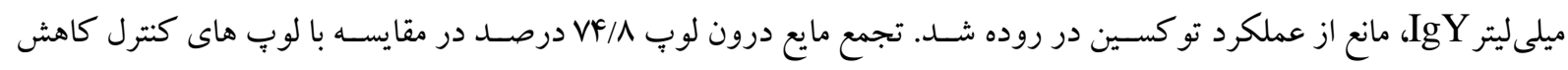
يافت. نتيجه كيرى: نتايج به دست آمده بيانكر آن است كه مىتوان از آنتىبادى مرغى اختصاصى عليه بروتئين نوتر كيب LTB به عنو إنوان

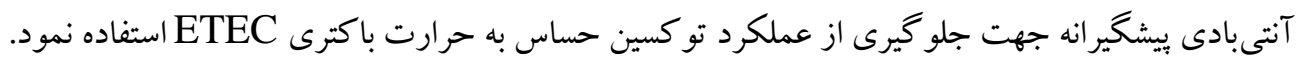

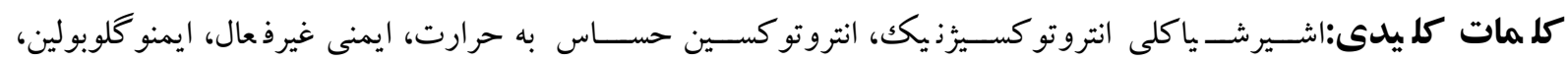
فاكتوربيمارىزايى

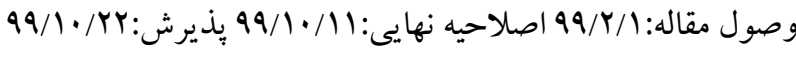


ساخت داروهاى جديد مىباشد(A). آنتىبادىهاى برند كان

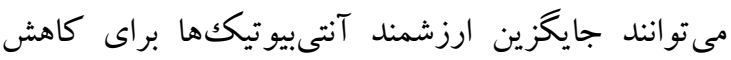

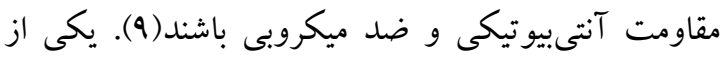
راههاى ممكن جهت بيشخيرى و درمان اين عفونت ، توليد

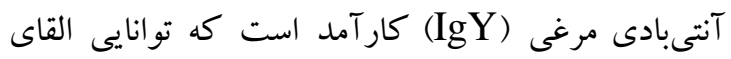
ايمنى در برابر اغلب سويههاى باكتريايى را داشته باشد.

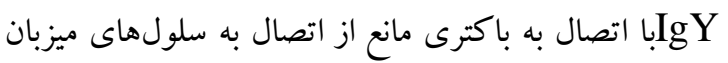

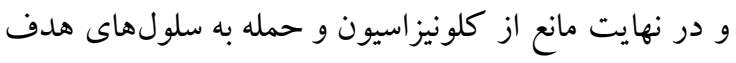
و ايجاد ايمنى غيرفعال مىشود(1)

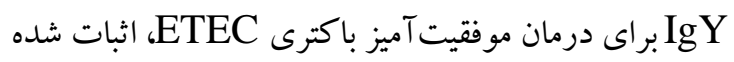
است (Y (I). ويز گىهاى IgY مانند توليد آسان و ارزان، حفاظت از حقوق حيوانات، عدم واكنش با سيستم كميلمان و عدم باسخ به فاكتورهاى روماتوئيدى، راه را براى استفاده از

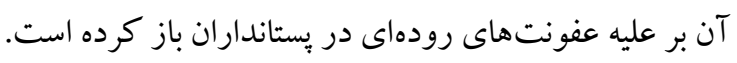

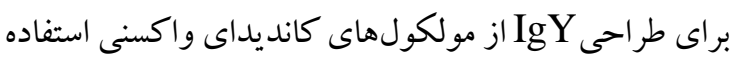

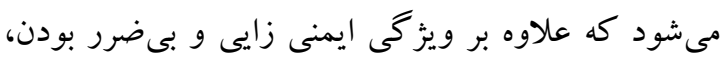

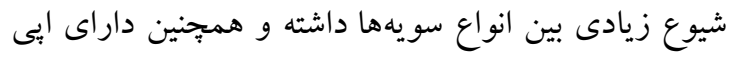
توٍ هاى مشتر كك و محافظت شده باشند .يكى از اصلى ترين

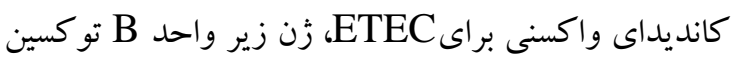
حساس به حرارت است كه قسمت اتصالى تو كسين را شكل كيرندهاى g $\quad 9$ داده

(GM1) monosialotetrahexosylganglioside سطح سلولهاى إيتليالى روده اتصال مىيابد. ززارشهاى

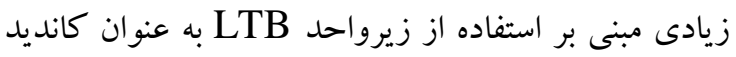

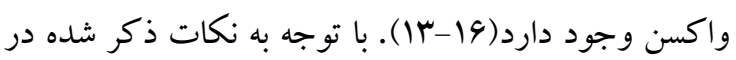

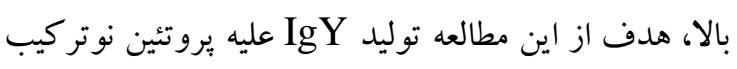

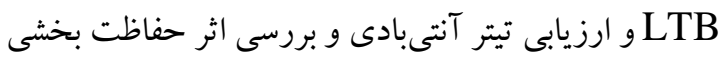
توليد شده بر مهار كلونيزاسيون و اثرات تو كسين IgY

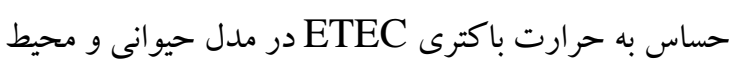
In vitro

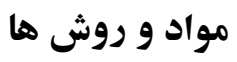
نوع مطالعه
مقدمه عفونتهاى رودهاى و بيمارىهاى اسهالى هنوز هم يكى از

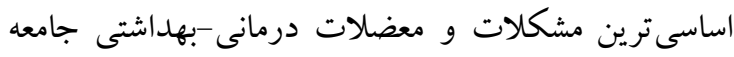
جهانى به ويزه در كشورهاى در حال توسعه به شمار

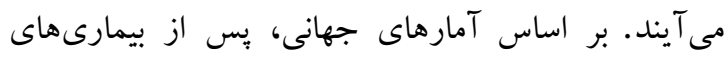

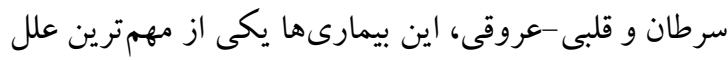

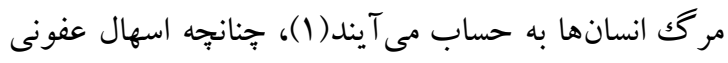

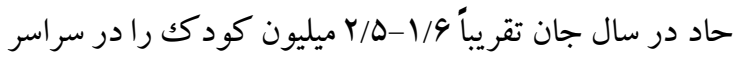
جهان مى كيرد (ץ, r). باكترى اشيرشياكلى انتروتو كسيز نيك رايجترين علت اسهال مسافران و همجينين عامل (ETEC)

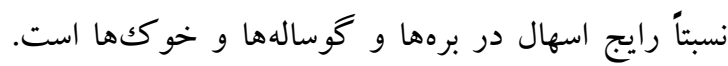
ETEC مىتوان به فاكتورهاى كلونيزاسيون، توكسين مقاوم به حرارت و حساس به حرارت اشاره نمود. ETEC فاكتورهاى كلونيزاسيون به سطح سلولهاى إيتليال روده

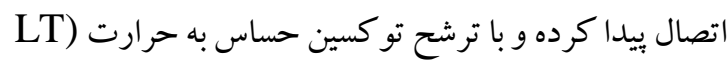

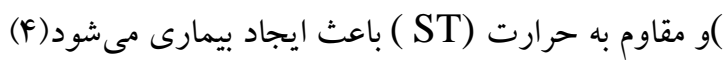

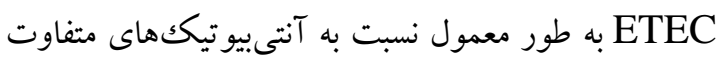

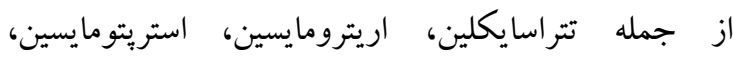

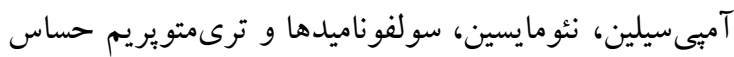

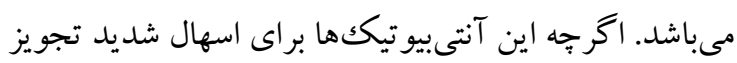

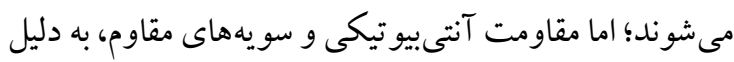
توانايى زياد اين باكترى در تبادل بِاسميدهاى مقاوم، هر

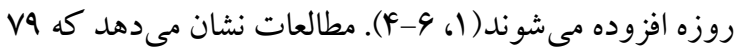

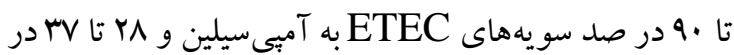
صد به ترىمتويريم و تعداد اندكى هم به افلو كساسين مقاوم

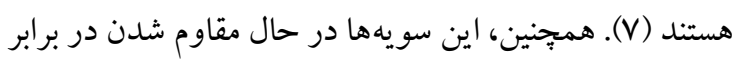

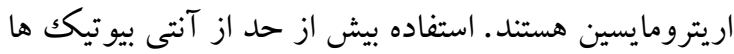
تهديدى واقعى براى جوامع بشرى است كه روش هاى جديد

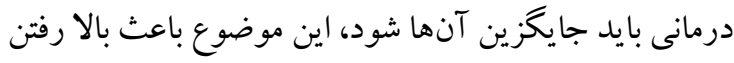

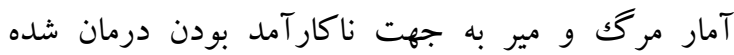

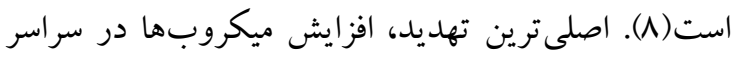

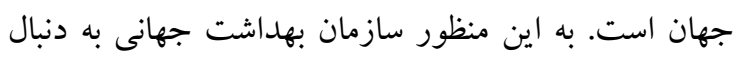


و مر حله طويل شدن در دماى VY درجه سانتى گر اد به مدت F. ثانيه و سيكل بايانى مربوط به مر حله طويل شدن در دماى Vr درجه سانتى گر اد به مدت ها دقيقه اجرا كرديد.

بيان و تخليص بروتئين نوتركيب LTB:

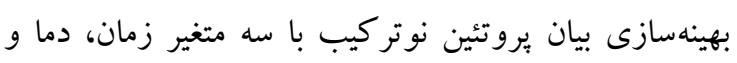

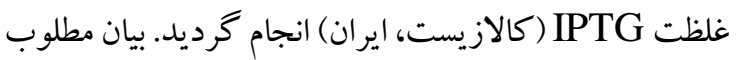
يروتئين نوتر كيب LTB با اضافه كردن •V ميلى كرم بر ليتر

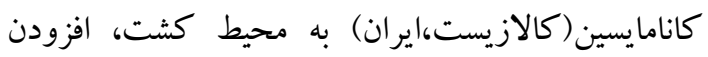

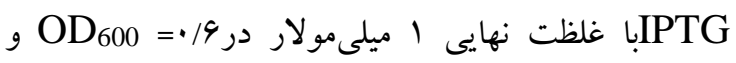

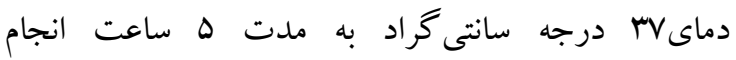

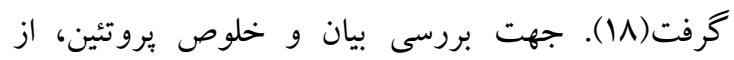
الكتروفورز Bio-Rad) SDS-PAGE،امريكا) استفاده شد(19). تخليص يروتئين نوتركيب LTB از فاز نامحلول عصاره سلولى به علت خلوص بالاى •9 درصد در اين فاز بدون نياز به ستون و تنها از طريق شستشوى اجسام تودهاى(inclusion bodies) صورت بذيرفت. در اين روش به رسوب سلولى به ازاى هر ميلىليتر، •^ ميكروليتر بافر (pH=^ Tris- $\mathrm{HCl}$ ، $\mathrm{NaH}_{2} \mathrm{PO}_{4}$ ) TE اضافه گرديد، سبس 9 بار عمل سونيكاسيون (قدرت •V درصد،

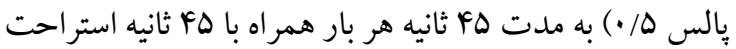
در يخ، روى نمونه انجام گرفت. سلولهاى ليز شده به مدت مدات

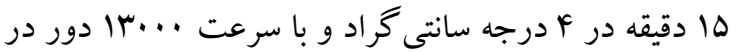

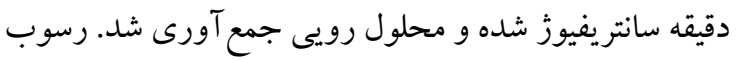
حاصل بار ديخر مانند مرحله قبل در بافر TE يكنواخت و سانترفيوز خرديد. رسوب به دست آمده از مرحله دوم به ازاى هر ميلى ليتر در •ميكروليتر بافر B حاوى اوره ممولار حل

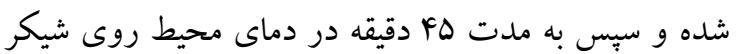
اوربيتال(vision، هند) قرار داده شد و در نهايت سانتريفيوز

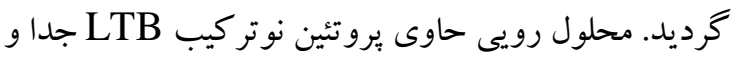
به ميكروتيوب جديد منتقل شد. تعيين غلظت يروتئين برونين موجود در محلول هاى حاصل از تخليص، با روش برادفورد

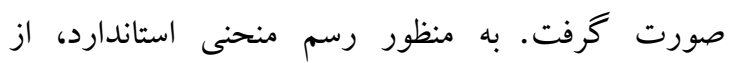

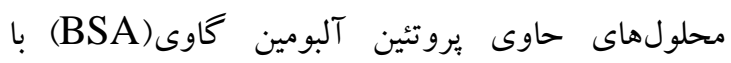

در اين مطالعه تجربى-آزمايشكاهى كه در سال ^هسا با كد اخلاق . . وكتور بيانى pET28a واجد زٔن كد كننده LTB اهدا شده توسط دكتر نظريان (19)، ميزبان بيانى اشريشياكلى ( E.coli

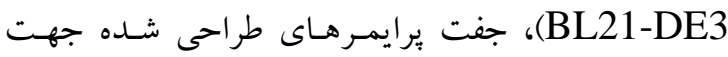
تائيد سازه زنى، محيطهاى كشت واجد و فاقد آنتىبيوتيك تصن براى كشت ميزبان بيانى، محيط كشـتهـاى سلولى براى رشد

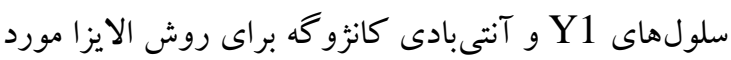

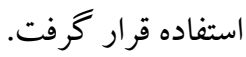

انتقال سازه زنى به ميزبان بيانى E.coli با استفاده از روش شوك حرارتى(IV)، پِاسميد حاوى زن

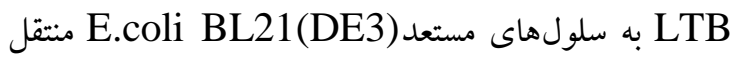
گرديد. در نهايت سلولهاى E.coli نوتركيب بر روى سلهاي

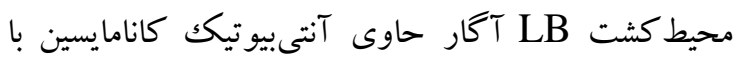
غلظت نهايى •^ميكرو گرم بر ميلى ليتر كشت داده و مرحله

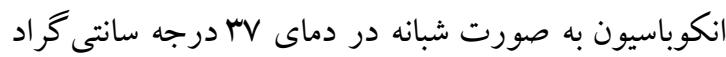
انجام گرفت. از ميان كلونهاى بهدست آمده، تعدادى كلنى

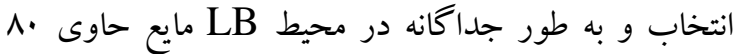
ميكرو گرم بر ميلىليتر كانامايسين به مدت يكك شب در شيكر

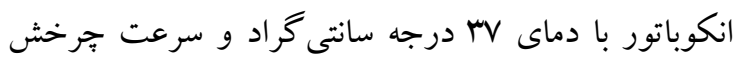

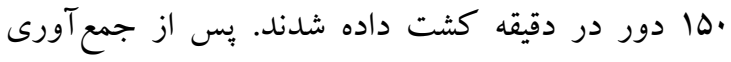
سلولها، واكنش PCR با استفاده از سوسِانسيون سلول

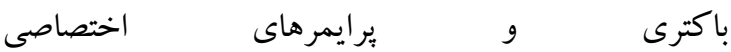
و TGTGCAGAATTCGCTCCTCAGTC TTACAAGCTTCTAGTTTCCATACTGA در حجم ها ميكرو ليتر شامل T/ه ميلىمولار TTG

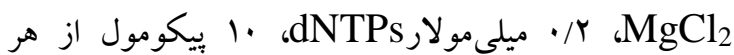
يرايمر، ז واحد آنزيم Taq DNA polymerase و ه/ه ميكرو ليتر از بافر 10X PCR انجام شد. شرايط خرخه

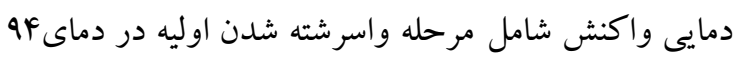

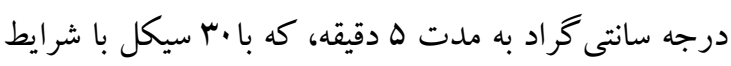

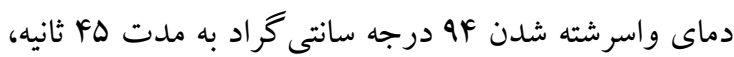

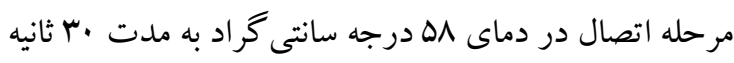


براى ايمنىزايى در مرغها (مرغ مادر بيوند،ايران)، مقدار ب.

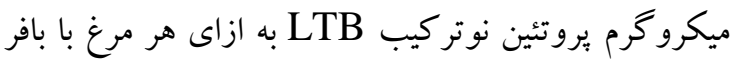

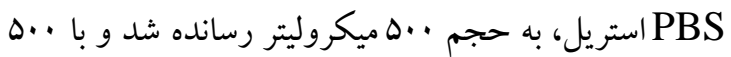

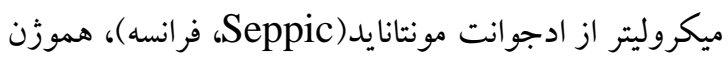
و به صورت داخل عضلانى به جهار قسمت از عضله سينه

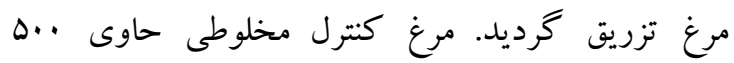
ميكروليتر بافر PBS به همراه . .ه ميكروليتر از ادجوانت

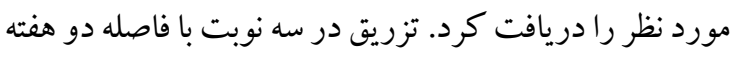

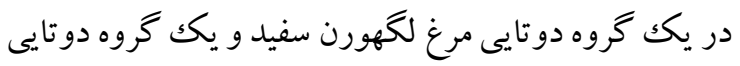

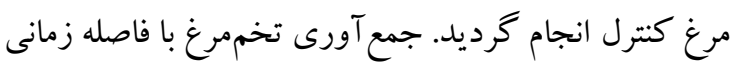

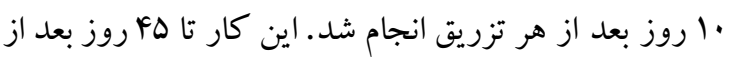
آخرين تزريق نيز ادامه بيدا كرد. تخليص IgY اختين تزريق تير در اين تحقيق از روش ترقيق اسيدى و ترسيب نمكى براى تخليص آنتى بادى مرغى از زرده تخم مرغ استفاده شد(·r).

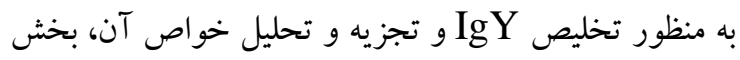

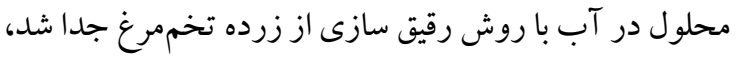
در اين روش زرده تخممرغ در شرايط اسيدى (pH=4) توسط آب رقيق شده و ץ روز در F- درجه سانتى گراد قرار

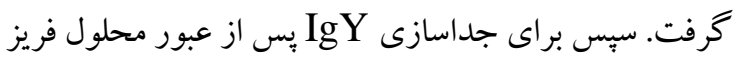
شده زرده تخممرغ از كاغذ صافى، IgY توسط سديم كلر ايد(كاسيين،ايران)، تغليظ و به مدت •r دقيقه و با دور SDS- توسط IgY رسوب داده شد.خلوص MF..

$$
\text { PAGE }
$$

بررسى تيتر آنتى بادى مرغى عليه يروتئين LTB: براى سنجش اختصاصيت IgY توليد شده عليه يروتئين بروني

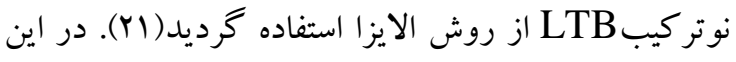

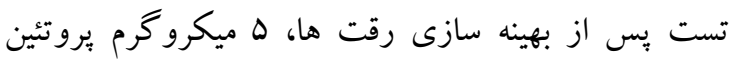

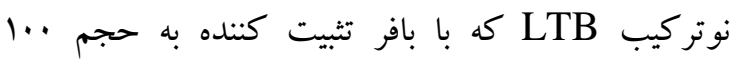

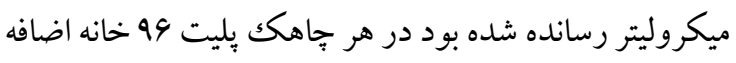

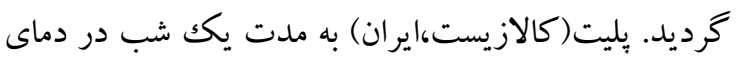

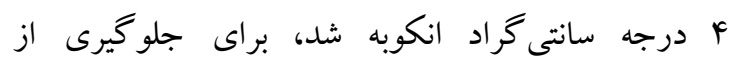
واكنشهاى ناخواسته آنتىبادى مرغى و آنتىبادى مرغى
غلظت هاى معِين استفاده شد. جذب آنها در طول موج هوها نانومتر به كمك دستكاه اسيكتروفتومتر اندازهيرى شد، سبس از دادههاى بهدست آمده منحنى استاندارد رسم گر ديد

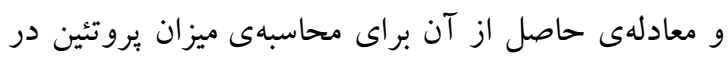

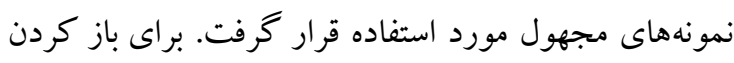

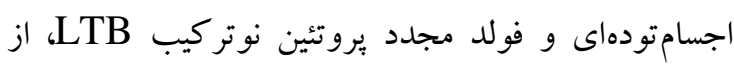
غلظتهاى مختلف محلول اوره (كاسبين، ايران) و كيسه دياليز با قطع rا كيلودالتون (كالازيست،ايران) استفاده شد.

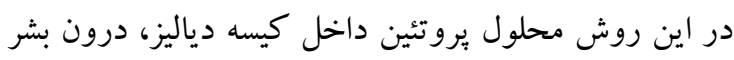

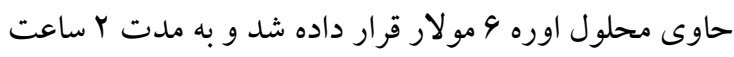

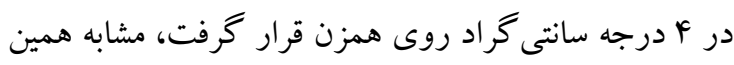

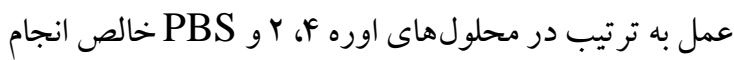

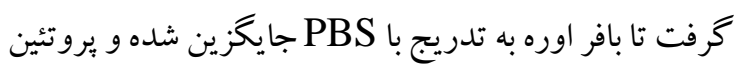
ساختار اصلى خود را باز يابد. تائيد بروتئين نو تر كيب LTB:

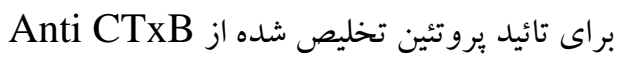

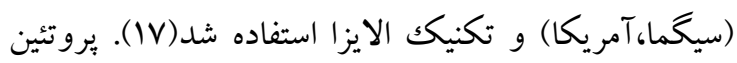

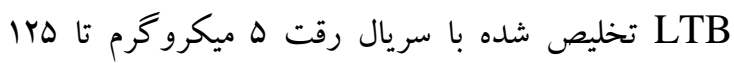

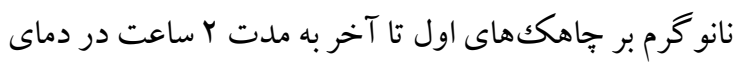

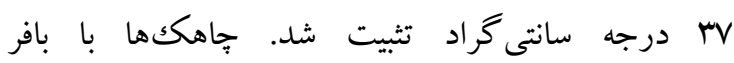
شستشو (PBS حاوى ه درصد توئين ·r) سه مرتبه شستشو

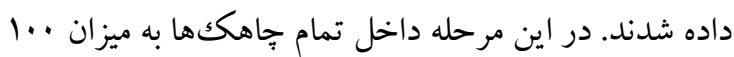

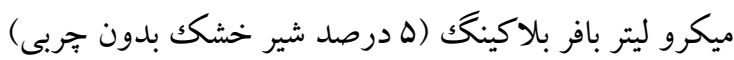
در بافر شستشو ريخته و به مدت ا ساعت در rV درجه

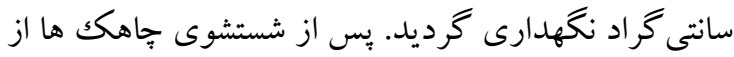

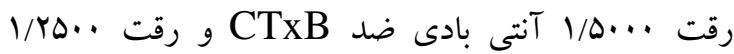

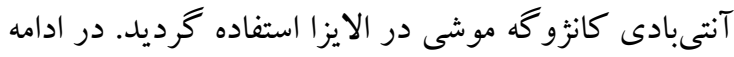
TMB به جاهك مها افزوده و

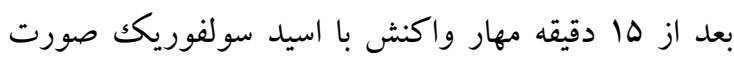

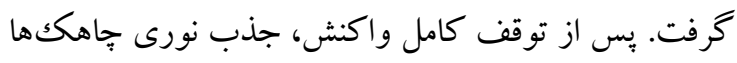

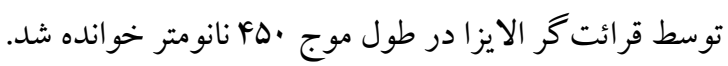

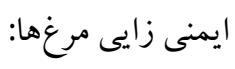


سلولهاى مجاور شده با نمونهاى مرغ ايمن و غير ايمن

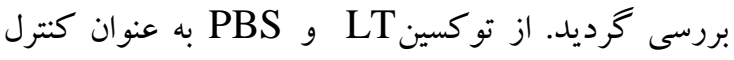
مثبت و منفى استفاده شد. بررسى ممانعت آنتى بادى از عملكرد تو كسين در لوبِ ايلئال: به منظور سنجش توانايى آنتىبادى در ممانعت از عملكرد

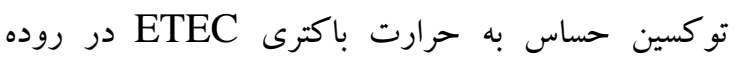
خر گُش (موسسه تحقيقاتى واكسن و سرمسازى رازى، ايران)

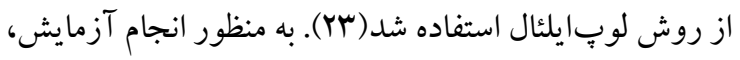
qr ساعت قبل از جراحى، غذاى يكك سر خركوش سفيد

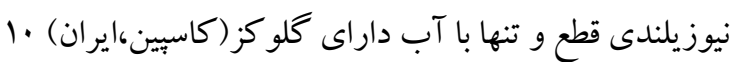
درصد تغذيه شد.خر گوش با تزريق ل.9 و . .1 ماكروليتر

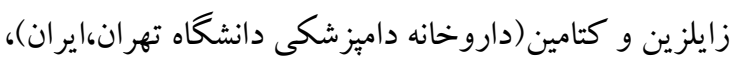
درون عضله بيهوش شد. بس از شكافتن شكم از بخش ايليوم

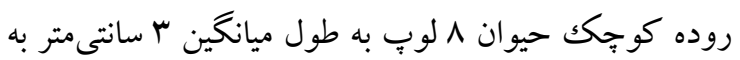
وسيله نخ بخيه (داروخانه داميزشكى دانشگاه تهران،ايران)

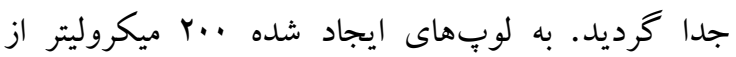

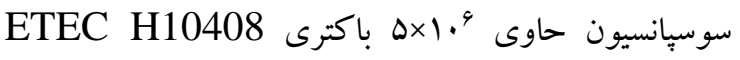

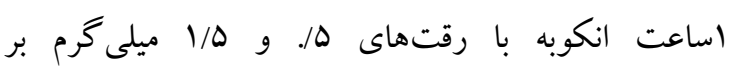

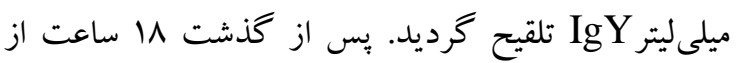

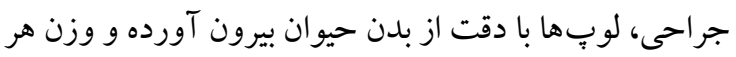

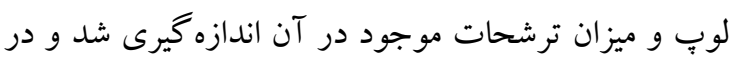

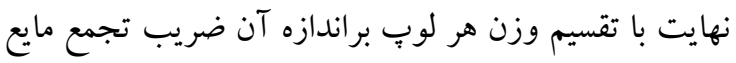
محاسبه گرديد.

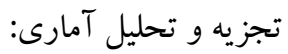
براى تعيين نرمال بودن دادهها از آزمون كلموكرافايرنوزوف استفاده شد و آناليز واريانس دادهها با استفاده از بران انواى يكك طرفه و مقايسه ميانكين گروه هاى تست و كنترل با استفاده از آزمون دانكن انجام گرفت. كليه عمليات آمارى با استفاده از نرم افزار SPSS 22 انجام شدون

يافته ها

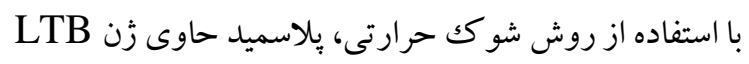
به سلولهاى مستعد (E.coli BL21(DE3 منتقل گرديد.
كانزو گه با كف جاهك هاى ميكرويليت، مناطق خالى از آنتىزن بلاك گرديد. براى اين كار، ..ب ميكروليتر از بافر بلاكينك ها درصد شير خشك بدون جربى

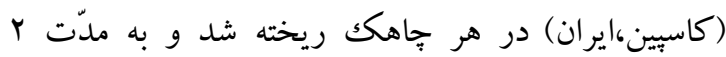

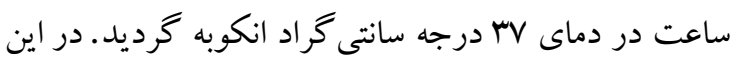

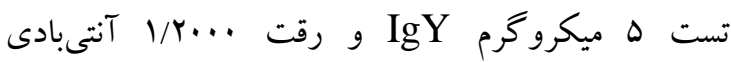

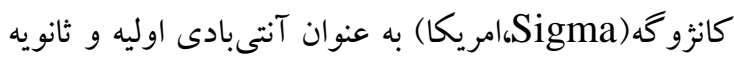

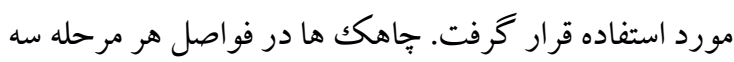

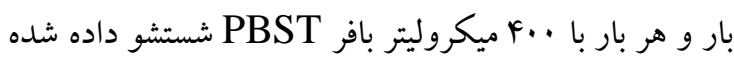

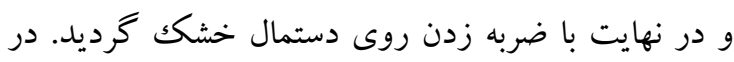

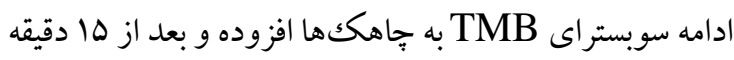

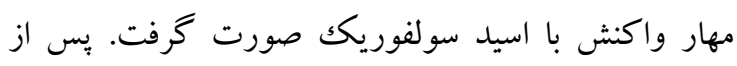
توقف كامل واكنش، جذب نورى جاهك ها توسط قرائت

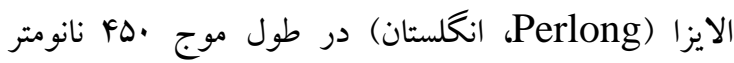

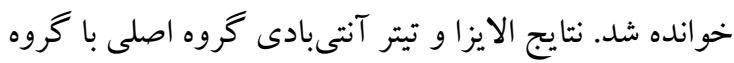
كنترل مورد ارزيابى و مقايسه قرار گرفت. بررسى ممانعت آنتى بادى از عملكرد تو كسين بر سلول Y1:

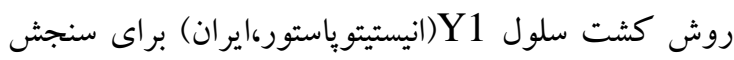
فعاليت IgY در مهار عملكرد تو كسين حساس به حرارت

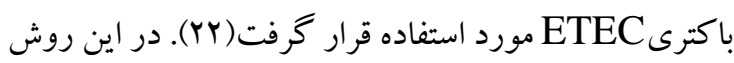
براى كشت سلول Y1 از محيط كشت Dulbecco's (DMEM)ModifiedEagleMedium ايران) و FBS (1.FBS درصد استفاده شد. تعداد ه.اسلول

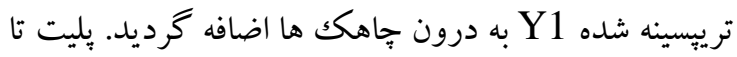
مدت زمان تشكيل تكك لايهسلولى در گرمخانه

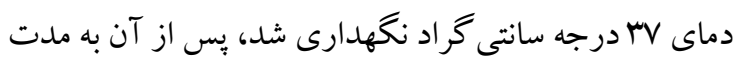

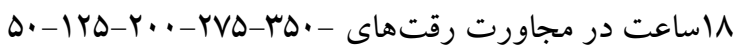

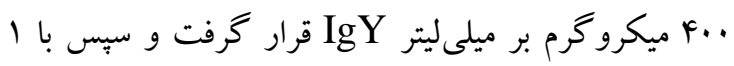

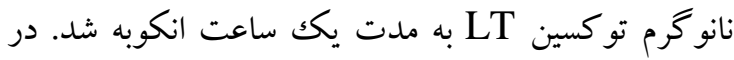

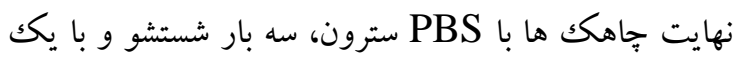

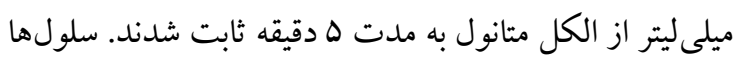

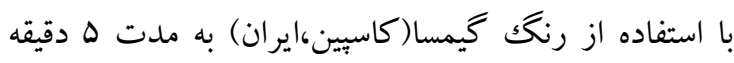
رنخك آميزى و با بافر PBS شسته شدند. شكل ظاهي 
شكل اديده مى شود محصول PCR با اندازه سبr جفت باز

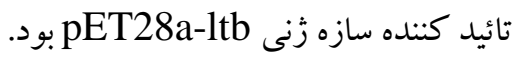

با استفاده از برايمرهاى اختصاصى زن كد كننده LTB، كلونىهاى رشد يافته باكترى بررسى شد. همانطور كه در

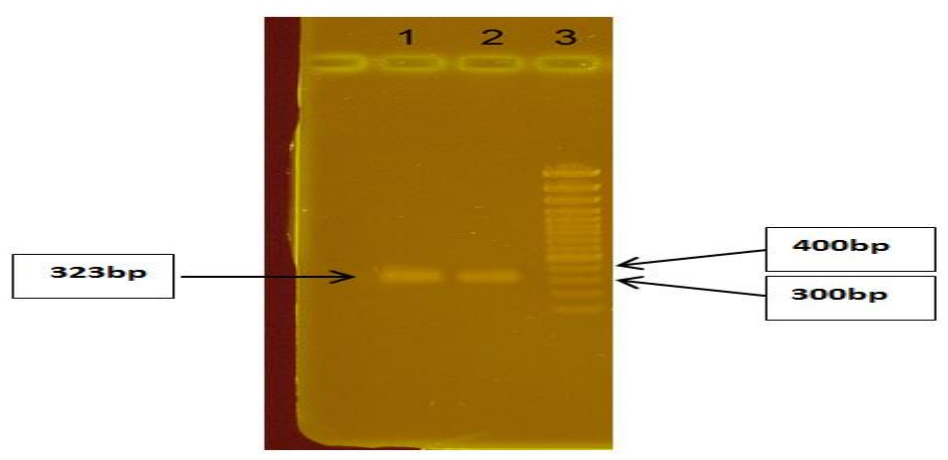

شكل 1 ـ الكتروفورز محصولات PCR تكثير شده جهت بررسى كلونهاى نوتر كيب

If با وزينه سازى بيان يروتئين نوتر كيب LTB

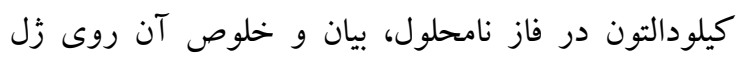

SDS-PAGE

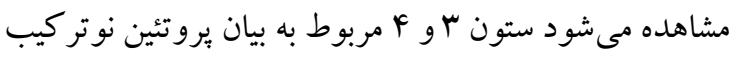
LTB

ستون ₹ بيانكر وزن ملكولى بروتئين بيان شده مىباشد. 100bp DNA ladder )DNA رديف ب: نشانگر اندازه

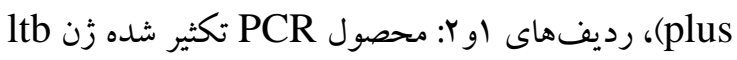
از كلونهاى نوتر كيب. تكثير قطعه زنى سبس جفت بازى تائيد

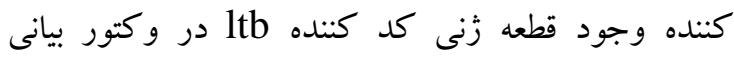
بود.pET28a

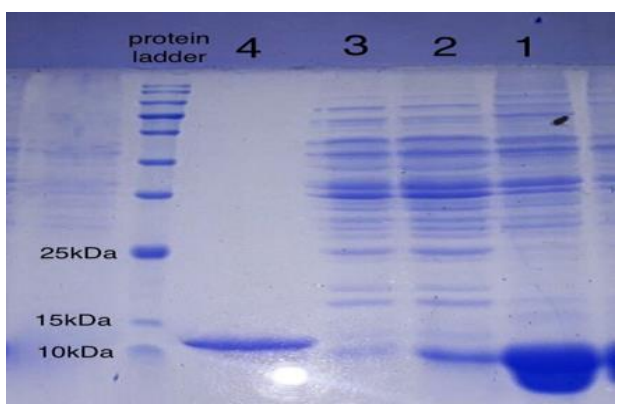

شكل ז. بررسى بيان و تخليص يروتئين نوتركيب LTB بر روى زل SDS-PAGE ז ا إرصد با رنككآميزى كوماسىبلو.

براى تائيد بروتئين نوتر كيب از روش الايزا و آنتىبادى ضد إند

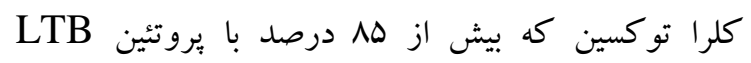

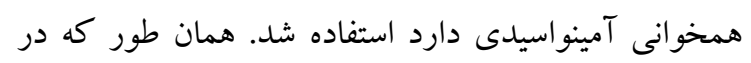

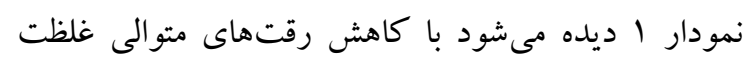

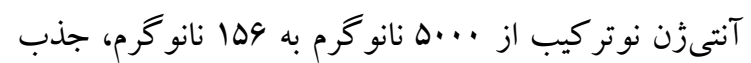

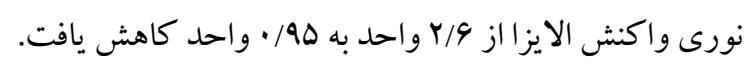
نتايج نشان داد كه آنتىبادى ضد كلرا توكسين توانسته بروتئين نوتر كيب LTB را شناسايى و با آن واكنش دهد.

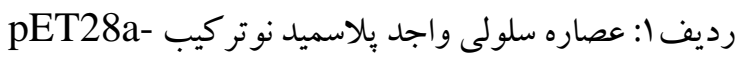

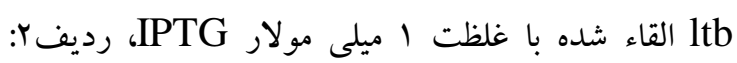

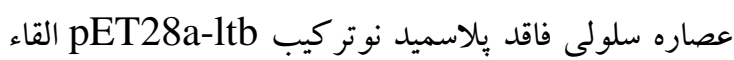

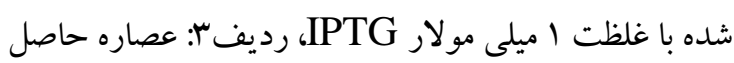

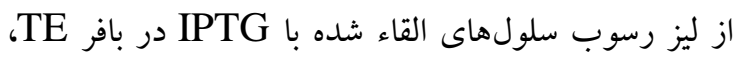

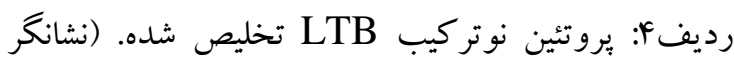

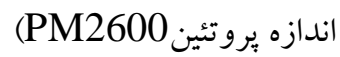




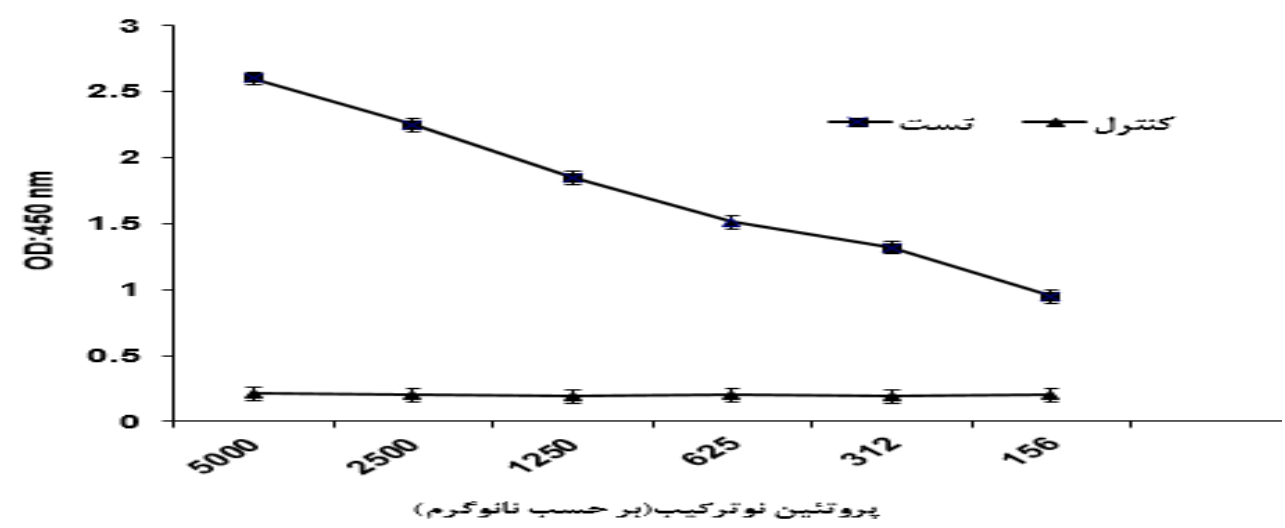

نمودار ا. تائيد يروتئين نوتر كيب LTB به روش الايزا با استفاده از آنتىبادى استاندارد ضد كلرا توكسين.

شد. شكل س الكوى الكتروفورز IgY ضد بروتئين نوتر كيب تخليص شده از زرده تخم مرغ با استفاده از كلريد

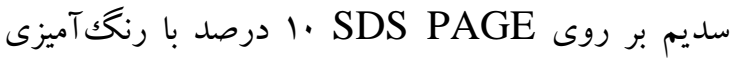
كوماسىبلو را نشان مىدهد. باند قطور مولكول كامل IgY خالص شده در شكل ديده مى شود. آنتىبادى مرغى عليه

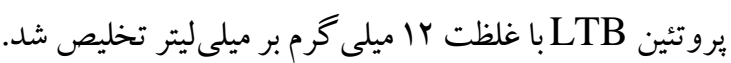

با كاهش غلظت آنتىزن نوتر كيب از ....ه نانو گرم به 109 نانو گرم، جذب نورى واكنش آنتى بادى اختصاصى و آنتىزن نيز از Y/9 به 9D/ • كم مى شود كه تائيد كننده اتصال اختصاصى آنتىبادى با بروتئين نوتر كيب است.

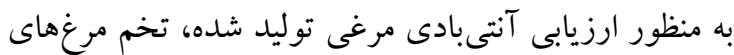
ايمن شده ده روز بِ از هر تزريق و هأ روز پِ از تزريق

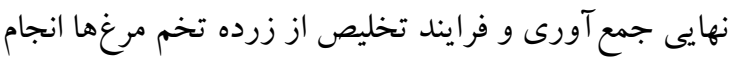

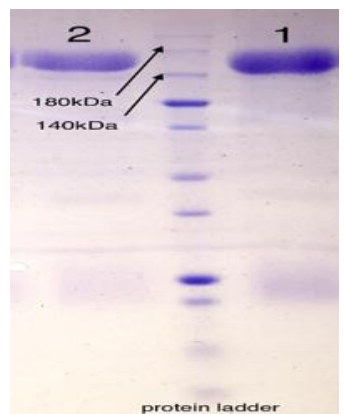

شكل r. الكتروفورز IgY ضد يروتئين نوتر كيب LTB تخليص شده از زرده تخممرغ با باستفاده از

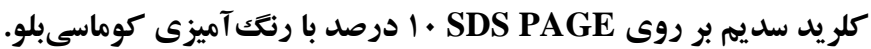

تجويزهاى اول، دوم، سوم و تخممرغهاى تست و شاهد جمع آورى و بعد از تخليص آنتىبادى آنها، آزمايش الايزا

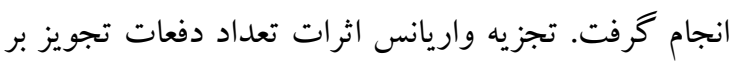
تيتر آنتىبادى انجام شد. بر اين اساس طرح آمارى براى

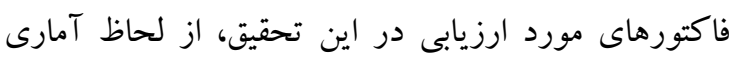

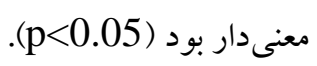

رديف او Y: نمونه IgY تخليصى تيمار شده با سمبل بافر فاقد

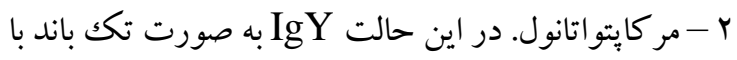

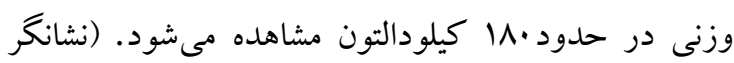

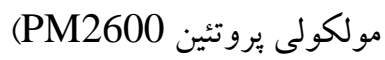
از آنتىبادىهاى تخليص شده درو ورتين واكنش الايزا استفاده

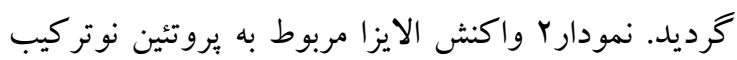
تخليص شده و آنتىبادى مرغى را نشان مىدهد. بعد از 
مشاهده شد( po.01)، در حالى كه تيتر آنتى بادى تجويز دوم و تجويز سوم تفاوت معنىدارى را نشان نداد

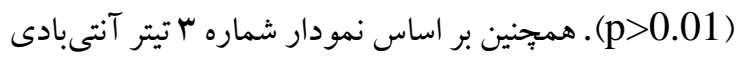

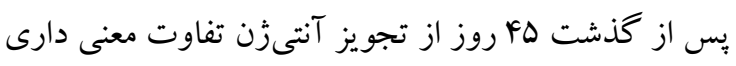

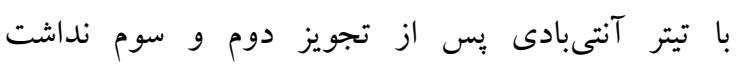
(p>0.01)
نتايج بهدست آمده از تيتر آنتىبادى نشان مىدهد كه در

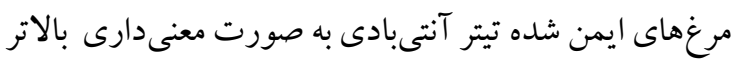

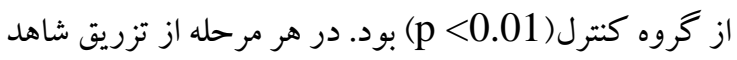
افزايش تيتر آنتىبادى بوديم به نحوى كه بيشترين ميزان

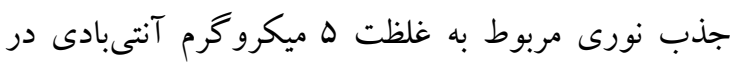
تزريق سوم Y/99 واحد بود. بر اساس نتايج به دست آمده

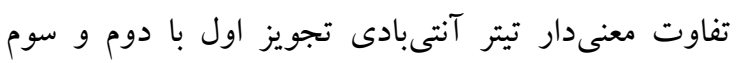

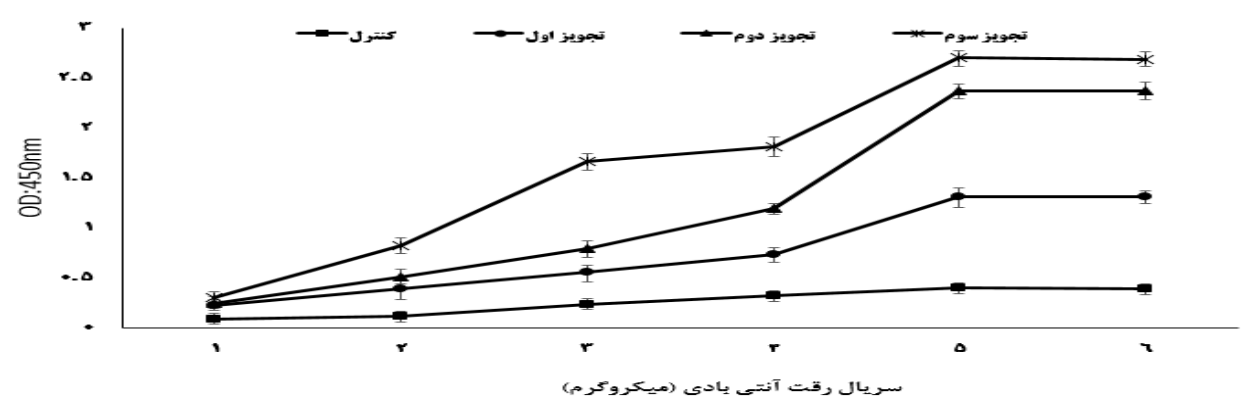

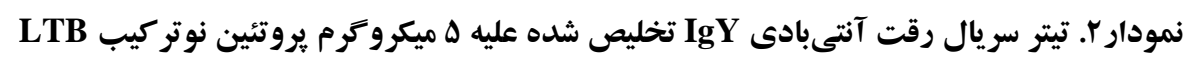
در فواصل زمانى تزريقهاى اول،دوم،سوم و قبل از تزريق.

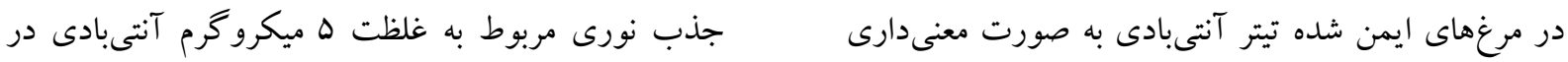

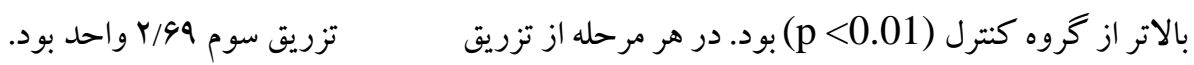

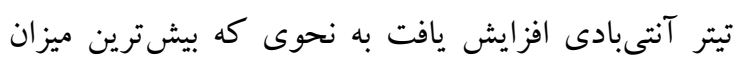

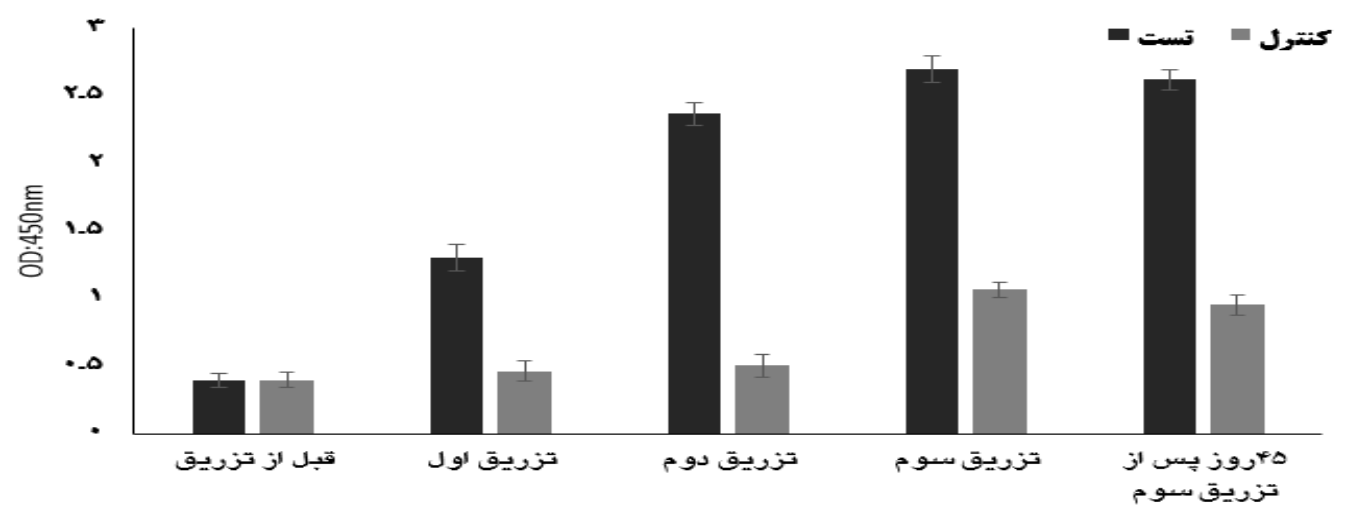

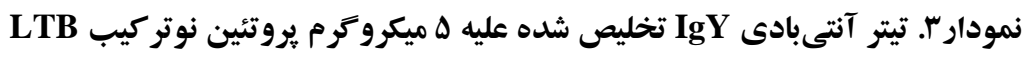

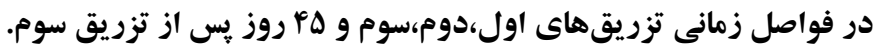

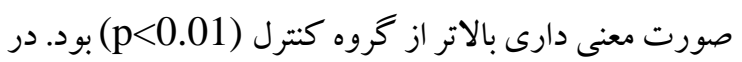
هر مرحله از تزريق تيتر آنتىبادى مرغى افزايش يافت بروه دترل
بررسى تيتر آنتىبادى IgY تخليص شده عليه يروتئين نوتركيب LTB در گروه ايمن و غير ايمن. همانطور در برد نمودار ديده مى شود در مرغهاى ايمن شده تيتر آنتىبادى به فيه 
مشاهده مىشود رقت 1YD ميكرو گرم بر ميلى ليتر آنتىبادى

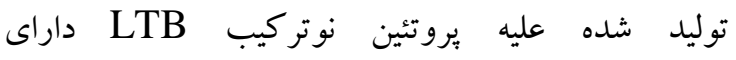

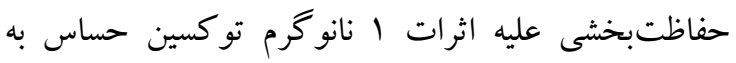
حرارت باكترى ETEC بر روى سلول Y1 است. در حالى بلى كه رقت •ه ميكرو گرم بر ميلى ليتر آنتىبادى توليد شده عليه

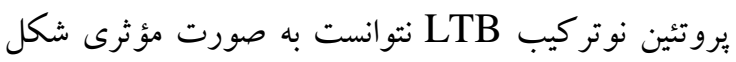
طبيعى سلولها را حفظ كند.

$$
\begin{aligned}
& \text { نحوى كه بيشترين ميزان OD مربوط به تزريق سوم و به ميزان }
\end{aligned}
$$

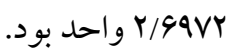

$$
\begin{aligned}
& \text { فعاليت آنتىبادى IgY در ممانعت از عملكرد تو كسين برد }
\end{aligned}
$$

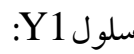

آنتىبادىهاى ايجاد شده بر عليه بروتئين نوتر كيب LTB

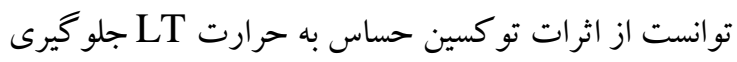

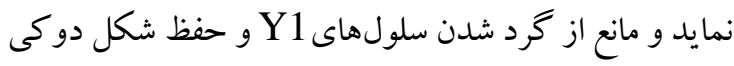

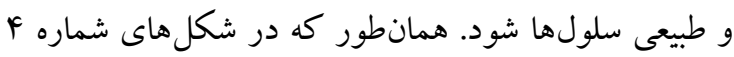
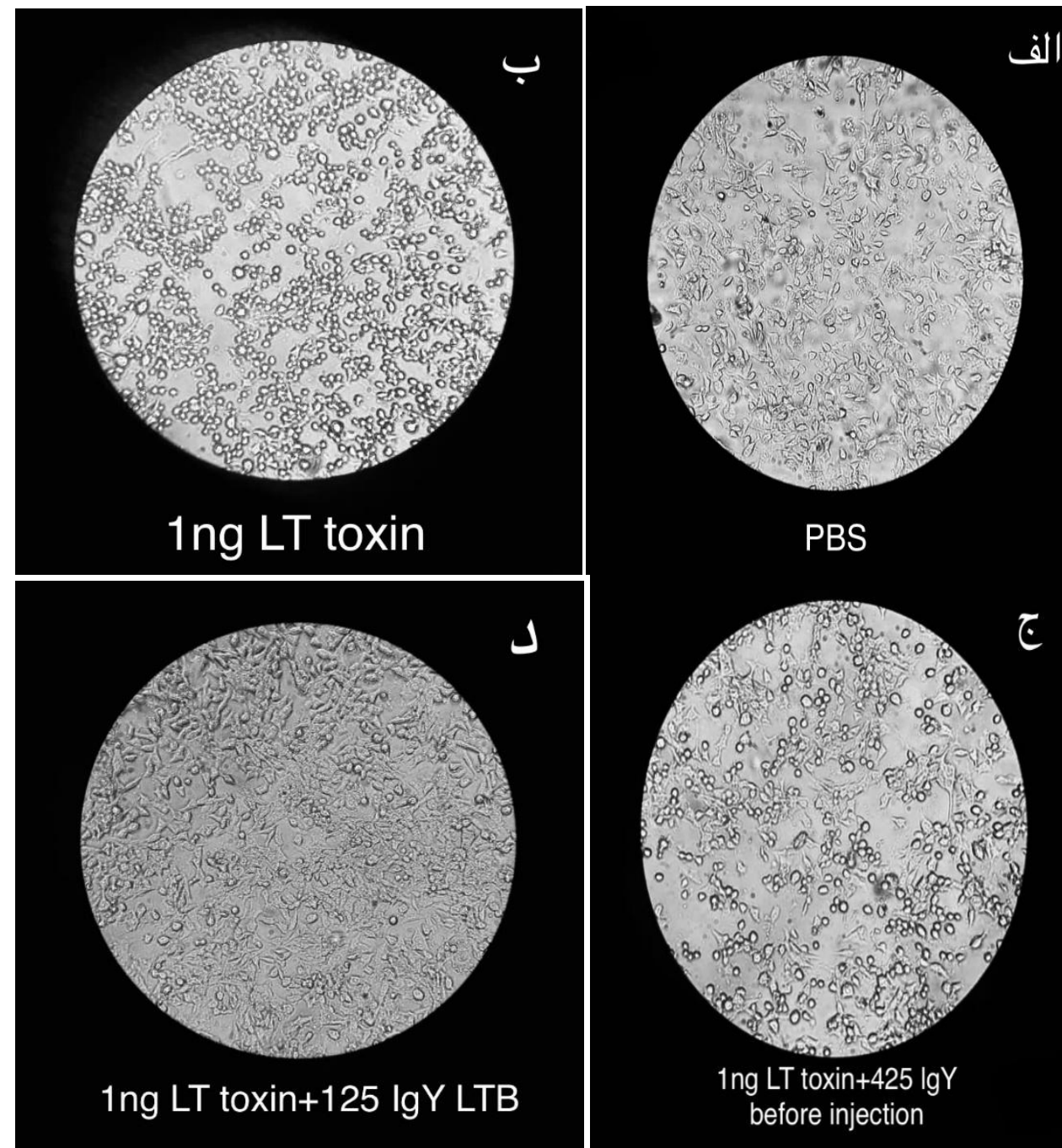

PBS

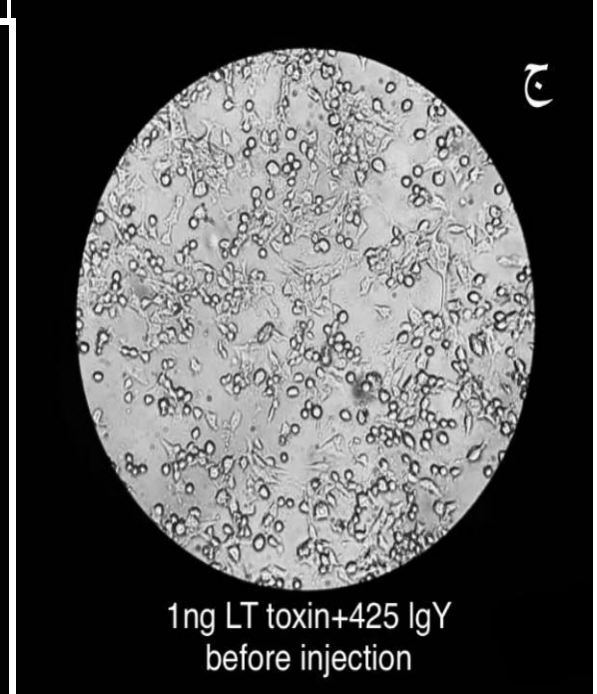

شكل †. بررسى ممانعت آنتىبادى IgY از عملكرد توكسين LT بر سلول Y1 
براى ارزيابى اثرات محافظتى، تجمع مايع در لوبههاى روده

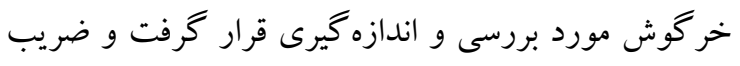

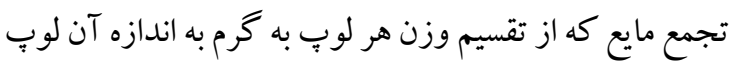
به سانتىمتر به دست مى آيد، محاسبه شد (نمودار شماره

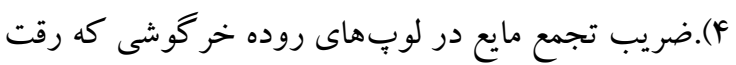

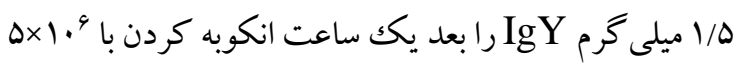

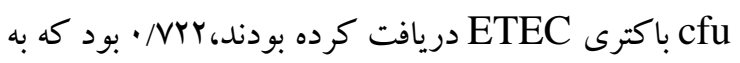

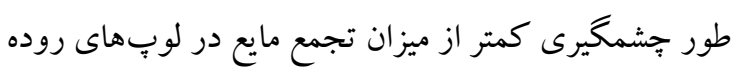

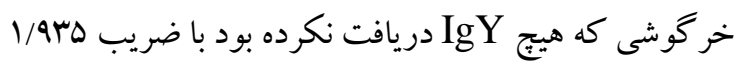

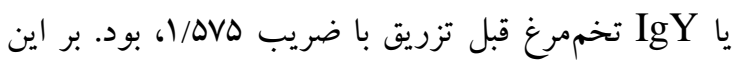

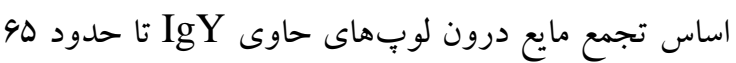
درصد كاهش داشته است.(شكل شمارهها )
الف: سلول Y1 طبيعى در مجاورت PBS ( تركيبات موجود در PBS و يا محيط تخليص توكسين باعث گرد شدن

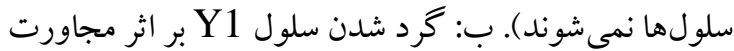

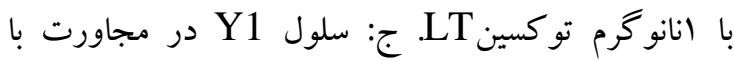

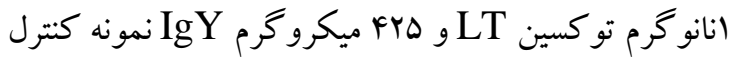

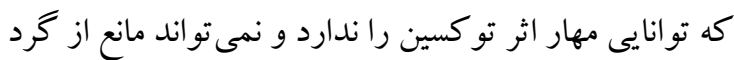

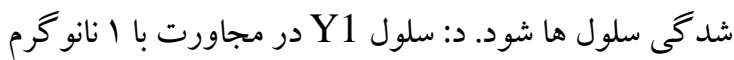

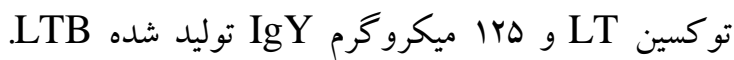
ممانعت آنتىبادى از عملكرد تو كسين و باقى ماندن سلولها به شكل دوكى و كشيده در شكل د به وضوح ديده مى شود.

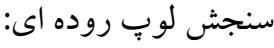

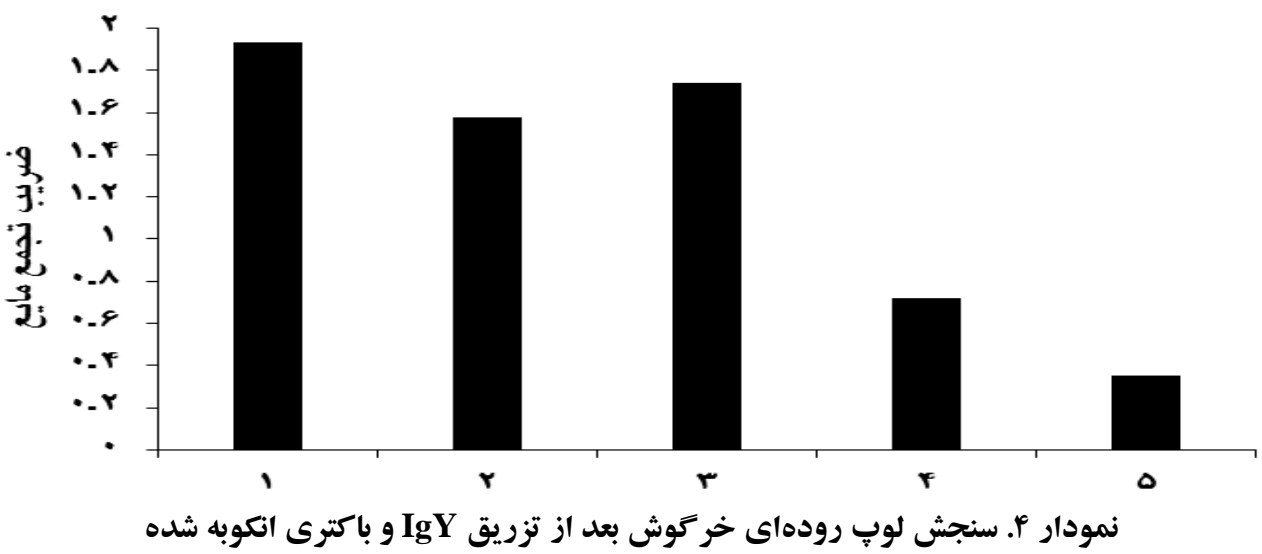

1/ه cfu $\Delta \times 1$ باكترى ETEC + LTB

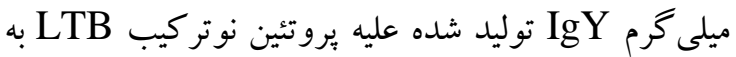

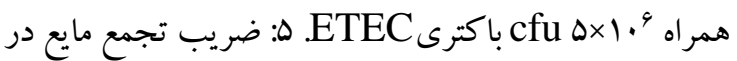
لو بِ خر گوش حاوى PBS به عنوان كنترل منفى.
1: ضريب تجمع مايع در لوبٍ خر گوش حاوى

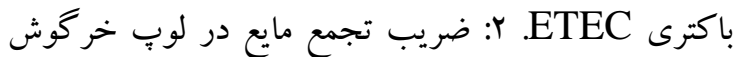

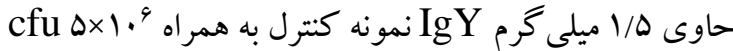

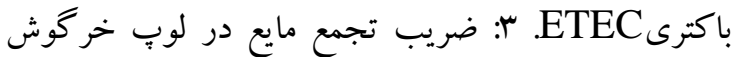

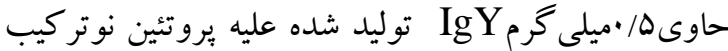




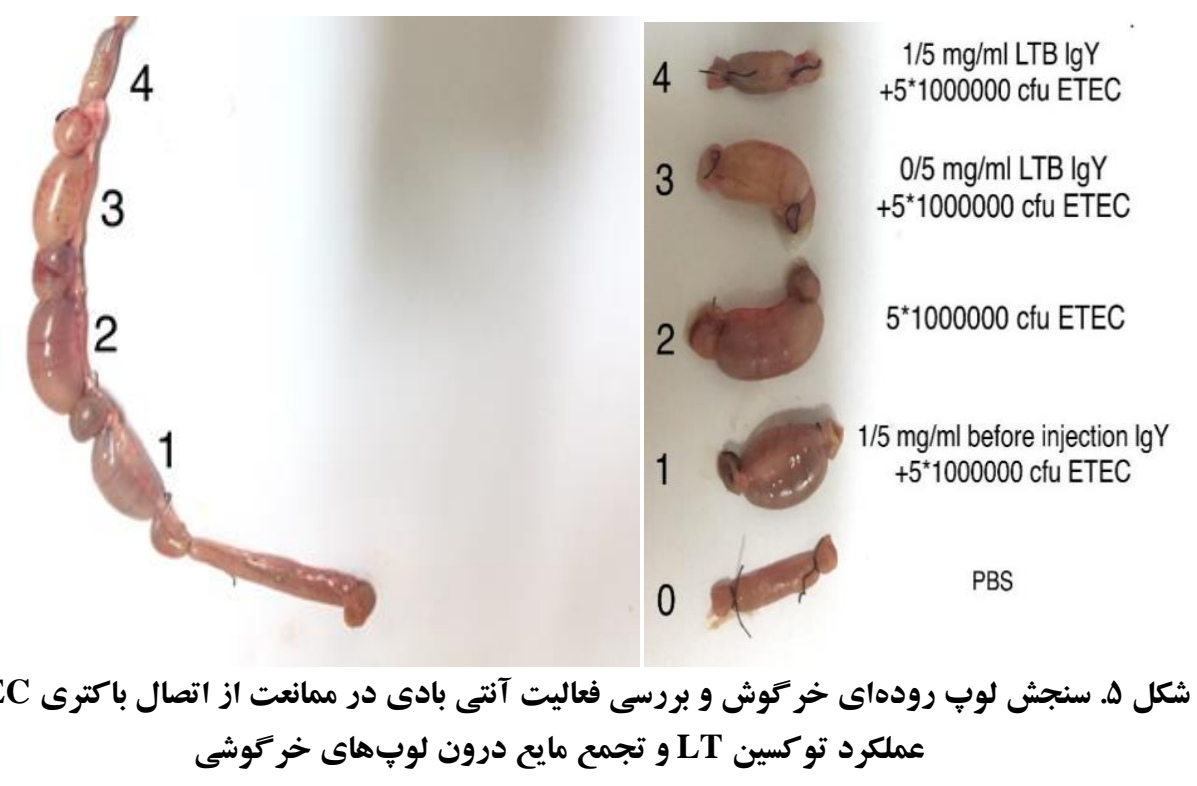

باكترى ETEC در طى دو مرحله باعث بروز بيمارى و عفونت اسهالى مىشود در مرحله اول با استفاده از فاكتورهاى اتصالى خود را به سطح سلول ميزبان نزديكك و به آن متصل مى گردد، در مرحله بعد با توليد و ترشح تو كسين، علائم در فرد بروز مى كند. بديهى است كه اگر بتوان مانع از اتصال و توليد تو كسين شد، مىتوان از بروز بيمارى و ياسخ مقاومتى عليه باكترى جلو گيرى كرد. بروتئين LTB يكى از عوامل اصلى حدتزاى باكترى مىباشد و در بسيارى از سويههاى بالينى وجود دارد. در مطالعات بسيارى از LTB به عنوان يك ليك اجوانت مناسب براى تحريك سيستم ايمنى عليه عوامل بيمارىزا استفاده شده است (rا-19). در سال هـ •ب مؤذنى و همكاران زن LTB را در مخمر ساكارومايسسسرويزيه بيان كردند و مطالعات آنها نشان داد كه LTB يك مه كانديداى واكسن مناسب و ارزان قيمت است (ها). خالصى و همكاران، زن LTB را به وكتور pET28a انتقال داده و درون E.coli همسانهسازى كردند و پِ از از بيان و تخليص يروتئين نوتركيب (YF)، آنتى بادى عليه آن در موش توليد شد، اين آنتى بادى مى توانست تو كسين LT را خنتى نمايد (TD). اين زير واحد بروتئينى علاوه بر اينكه سبب توليد آنتىبادى و ايجاد محافظت عليه تو كسين LT مى شود، خود به عنوان يكك ادجوانت زيستى مهم مطرح است كه ميتواند

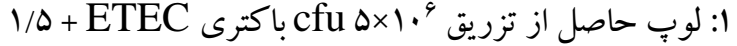
ميلى گرم بر ميلى ليتر از IgY تخممرغ قبل از تزريق.ب: لوب

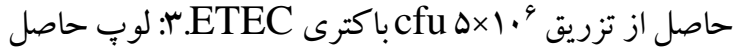

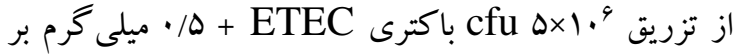
ميلى ليتر از IgY توليد شده عليه يروتئين نوتركيب LTB لوب حاصل از تزريق ميلى گرم بر ميلىليتر از عليه يروتئين نوتركيب IgY

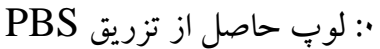

كشورهاى در حال توسعه با آب و هواى گرمسيرى جزو مناطقى هستند كه با معضلات بهداشتى از جمله اسهال ناشى از ETEC خصو صاً در كود كان زير هـ سال، مواجه است. به همين دليل، تلاش براى درمان عفونتهاى ETEC يكى از اهداف اصلى محققان اين رشته مىباشد. با توجه به ظهور سويههاى مقاوم به آنتى بيوتيكك، استفاده از آنتى بادى ها به منظور ايجاد ايمنى غيرفعال و مقابله با عفونتهاى اسهالى حائز اهميت است. ETEC نسبت به آنتىبيوتيكهاى بسيارى حساس است و به علت توانايى زياد سويههاى مقاوم ETEC در تبادل يَاسميدهاى مقاوم، مقاومت آنتىبيوتيكى آنها رو به افزايش است (1, f-4). عملكرد 


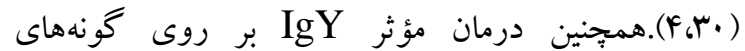
هليكوباكتر ييلورى، سالمونلاو رتروويروس ها نشان داده شده است (اس). خانم ويس ملكشاهى و همكاران تو انستند با گاواز IgY به معده موشهاى داراى زخم معده ناشى از آلودهسازى با هليكوبا كتر ييلورى را در مان كنند(Yr). Copelan در سال

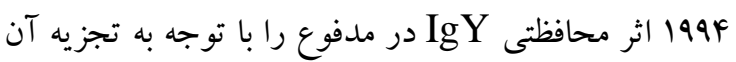

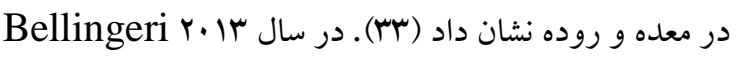
فعاليت آنتىبادىهاى تخممرغى در مقابله با باكترى ETEC

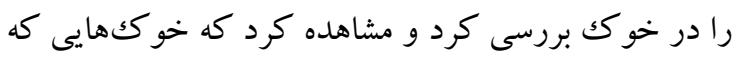

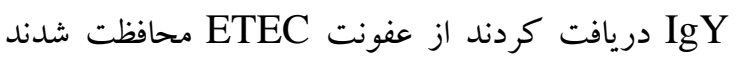
(MF) . مصرف طولانى مدت و هر روزه زرده تخممرغ حاوى

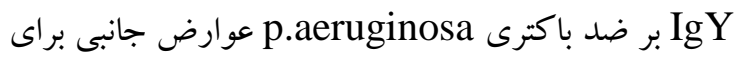

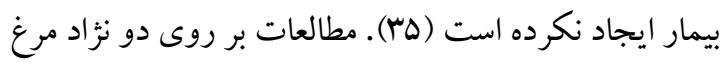

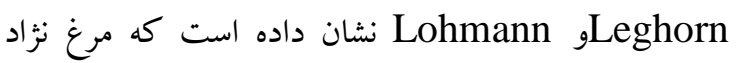
Leghorn توانيى توليد آنتىبادى بيشترى دارد، در اين

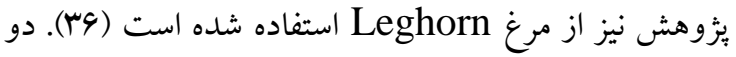
روش متداول براى تخليص آنىىبادى مرغى عبارت اند از

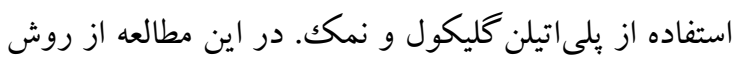

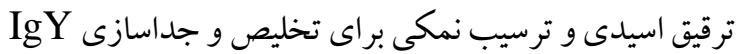
از زرده تخممرغ استفاده شده است(•r). از آنجاكه در الايزا از يروتئين نوتركيب LTB به عنوان آنتىزن و يروتئين تخليص شده از زرده تخممرغ به عنوان آنتىبادى استفاده شده است، اتصال آنتىبادى كانزو گه مرغى با بروتئين تخليص

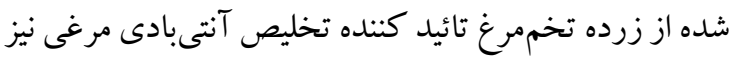

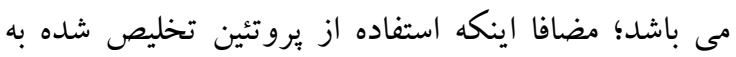

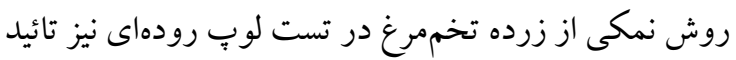

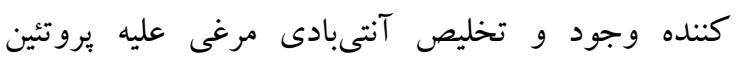

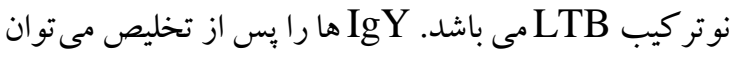

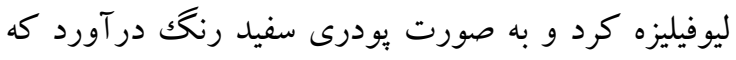

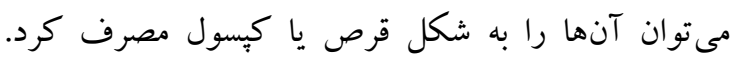
مطالعات نشان داده كه يخ زدن و يا خشك كردن دون در اثر سرما

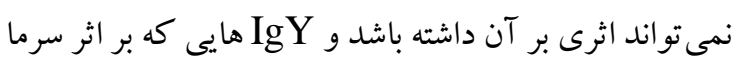

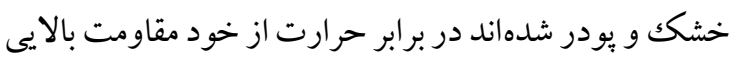

سبب برانگيختن ياسخهاى ايمنى از جمله ايمنى مخاطى شود

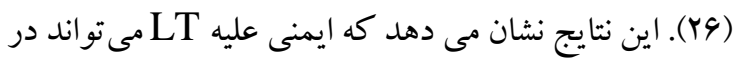
محافظت عليه ETEC نقش مؤثرى داشته باشد. سليميان و همكاران نيز اقدام به توليد بروتئين LTB به صورت الحاق بات بال

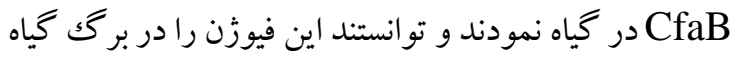

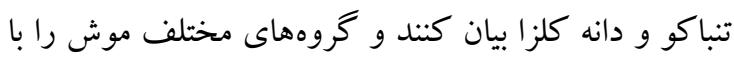

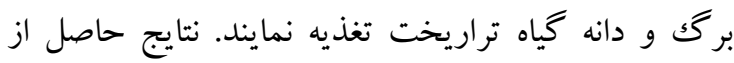

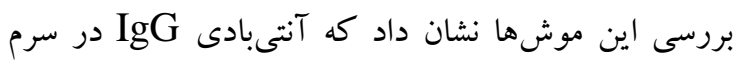
موش و IgA در سرم و مدفوع موش عليه فيوزن بروتئين

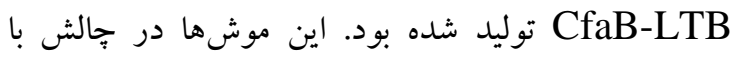
باكترى زنده ماندند (YV). در مطالعات ساير محققان بررسى

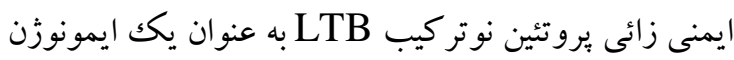

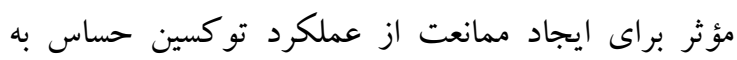

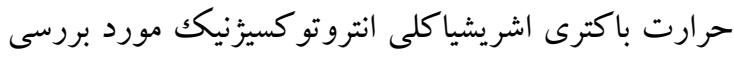

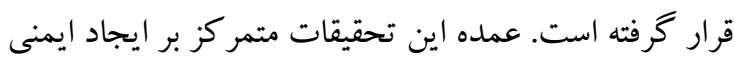
فعال بوده است. در تحقيق حاضر با توجه به نتايج كاربرد

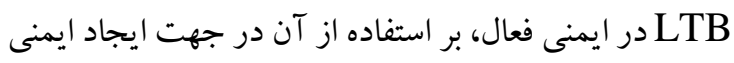
غيرفعال با استفاده از آنتىبادى با منشأ برند كان تأكيد شده إنها است كه تا كنون در كشور گزارشى در اين مورد ارائه نشده است. استفاده از IgY داراى مزاياى بسيارى است كه از جمله آنها مىتوان به مقرون به صرفه بودن، تخليص آسان، توليد در مقادير بالا، غيرتهاجمى بودن روش و عدم فعال نمودن

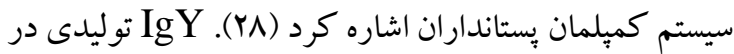

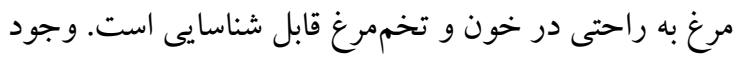

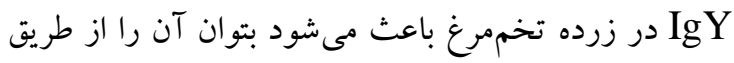
خوراكى مصرف كرد. اگرجه اين احتمال وجود دارد كه به به

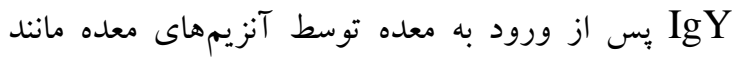

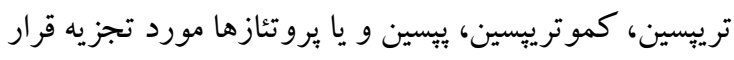

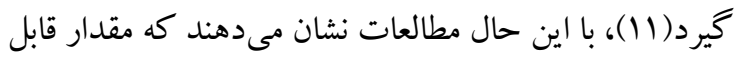

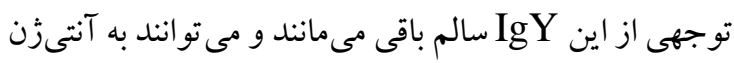

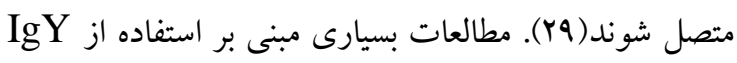

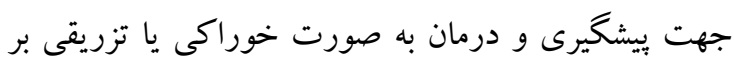

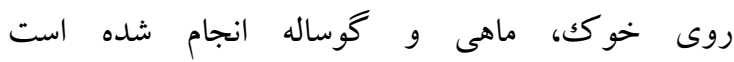


تو كسين حساس به حرارت LT جلو گيرى نمايد و مانع از

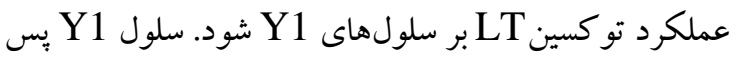
از مو اجهه با تو كسين LT به واسطه افزايش cAMP و تغيير در اسكلت سلولى، از حالت يهن، صاف و زائد دار به صورت سلولهاى گرد در آمد، با خنثى سازى تو كسين و افزودن آن

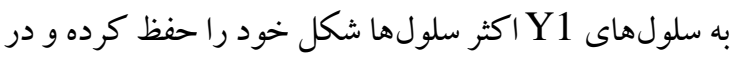
حالت طبيعى باقى ماندند. در تست سنجش لوبِ رودهاى

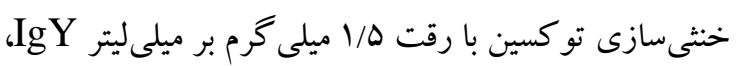

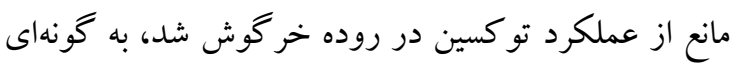

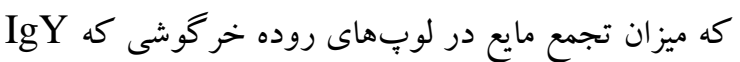

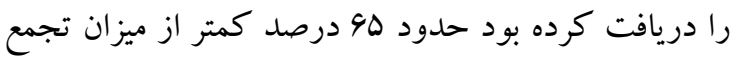
مايع در لوب هايى بود كه IgY دريافت نكرده بودند. به عنوان جمع بندى، نتايج تحقيق نشان مى دهد كه IgY توليد شده

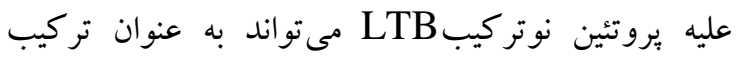
يشيخيرانه جهت ايجاد ايمنى غير فعال عليه اسهال ناشى از باكترى ETEC مورد توجه قرار گيرد.

\section{تشكر و قدردانى}

بدينوسيله از شوراى محترم يثزوهشى دانشگاه شاهد به دليل حمايت مالى و فراهم آوردن امكانات لازم جهت انجام اين

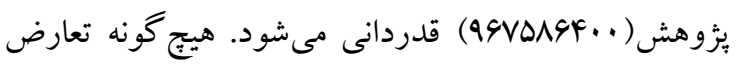
منافع توسط نويسند كان وجود ندارد.
را نشان مىدهند و تغييرى نمى كنند. بֶايدارى IgY صِ از تخليص آن بسته به شرايط مى تواند تا خند سال باشد(TV).

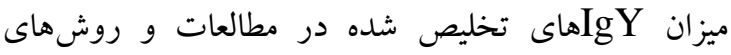
مختلف، متفاوت است. در مطالعاتى كه توسط Pauly و

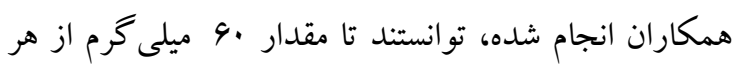

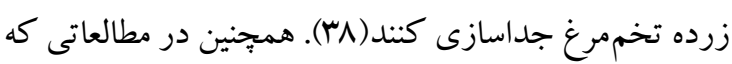

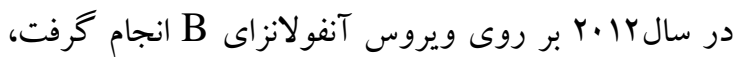

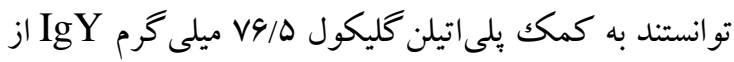

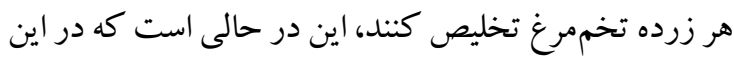

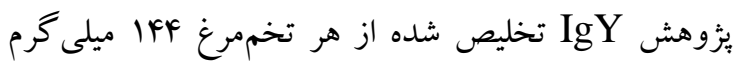
است كه در مقايسه با مطالعات يُيشين از بازده بالايى برخوردار

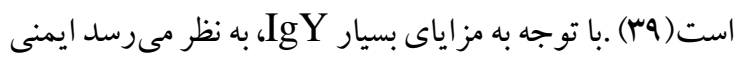

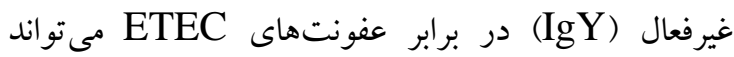
جايخزين مناسب آنتىبيوتيكك و يكك روش ايمونوترابى مؤثر باشد. نتايج تستهاى الايزا در اين يثزوهش نشاندهندهى تو انايى شناسايى آنتىزن توسط آنتىبادى است و همجنين

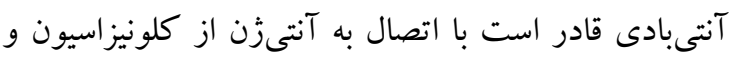

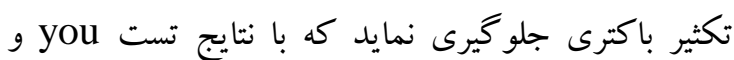

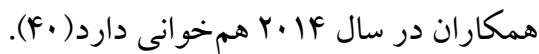

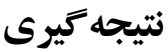
در تحقيق انجام شده IgY اختصاصى عليه يروتئين نوتر كيب

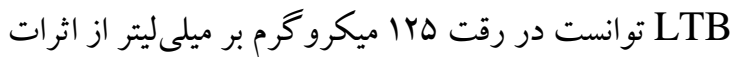

1.Svennerholm A-M, Tobias J. Vaccines against enterotoxigenic Escherichia coli. Expert Rev Vaccines. 2008;7(6):795-804.

2.Huilan S, Zhen LG, Mathan M, Mathew M, Olarte J, Espejo R, et al. Etiology of acute diarrhoea among children in developing countries: a multicentre study in five countries. Bull. World Health Organ. 1991;69(5):549.

3.Kosek M, Bern C, Guerrant RL. The global burden of diarrhoeal disease, as estimated from studies published between 1992 and 2000. Bull. World Health Organ. 2003;81(6):197-204.

4.Qadri F, Svennerholm A-M, Faruque A, Sack RB. Enterotoxigenic Escherichia coli in developing countries: epidemiology, microbiology, clinical features, treatment, and prevention. Clin. Microbiol. Rev.2005;18(3):83-465. 
5.DeBoy J, Wachsmuth I, Davis B. Antibiotic resistance in Enterotoxigenic and nonenterotoxigenic Escherichia coli. J. Clin. microbiol. 1980;12(2):264-70.

6.Nguyen TV, Van Le P, Le $\mathrm{CH}$, Weintraub A. Antibiotic resistance in diarrheagenic Escherichia coli and Shigella strains isolated from children in Hanoi, Vietnam. Antimicrob. Agent Chemother. 2005;49(2):816-9.

7.Stauffer WM, Konop RJ, Kamat D. Traveling with infants and young children. Part III: travelers 'diarrhea. J. Travel Med. 2002;9(3):141-50.

8. Nicklasson M. Studies on the expression and regulation of enterotoxins and colonization factors in enterotoxigenic Escherichia coli (ETEC). Inst of Biomedicine. Dept of Medical Microbiol. Immunol. 2008; 28(3)60-71

9.Aarestrup FM. Occurrence, selection and spread of resistance to antimicrobial agents used for growth promotion for food animals in Denmark: Chapter 1: Introduction. Apmis. 2000;108(S101):5-6.

10.Chalghoumi R, Beckers Y, Portetelle D, Théwis A. Hen egg yolk antibodies (IgY), production and use for passive immunization against bacterial enteric infections in chicken: a review. Biotechnologie, Agronomie, Société et Environnement. 2009;13(3):295-308.

11.Reilly RM, Domingo R, Sandhu J. Oral delivery of antibodies. Clin. Pharmacokinet. 1997;32(4):313-23.

12.Hatta H, Tsuda K, Ozeki M, Kim M, Yamamoto T, Otake S, et al. Passive immunization against dental plaque formation in humans: effect of a mouth rinse containing egg yolk antibodies (IgY) specific to Streptococcus mutans. Caries Res. 1997;31(4):268-74.

13.Anosova N, Chabot S, Shreedhar V, Borawski J, Dickinson B, Neutra M .Cholera toxin, E. coli heat-labile toxin, and non-toxic derivatives induce dendritic cell migration into the follicleassociated epithelium of Peyer's patches. Mucosal Immunol. 2008;1(1):59-67.

14. Fingerut E, Gutter B, Meir R, Eliahoo D, Pitcovski J. Vaccine and adjuvant activity of recombinant subunit B of E. coli enterotoxin produced in yeast. Vaccine. 2005;23(38):468596.

15.Rezaee MA, Rezaee A, Moazzeni SM, Salmanian AH, Yasuda Y, Tochikubo K, et al. Expression of Escherichia coli heat-labile enterotoxin B subunit (LTB) in Saccharomyces cerevisiae.J Microbiol. 2005;43(4):354-60.

16.Kordbacheh E, Nazarian S, Sadeghi D, Hajizadeh A. An LTB-entrapped protein in PLGA nanoparticles preserves against enterotoxin of enterotoxigenic Escherichia coli. Iranian J. Basic Med sci. 2018;21(5):517.

17.Kordbacheh E, Nazarian S, Hajizadeh A, Sadeghi D. Entrapment of LTB protein in alginate nanoparticles protects against Enterotoxigenic Escherichia coli. Apmis. 2018;126(4):320-8.

18.Hopkins R, Esposito D, Gillette W. Widening the bottleneck: increasing success in protein expression and purification. J Struct Biol. 2010;172(1):14-20.

19. Smith BJ. Chemical Cleavage of Proteins at Cysteinyl-X Peptide Bonds. Protein Prot. Handb. 2002 (pp. 503-506).

20.Hodek P, Trefil P, Simunek J, Hudecek J, Stiborova M. Optimized protocol of chicken antibody (IgY) purification providing electrophoretically homogenous preparations. Int J Electrochem Sci. 2013 Jan 1;8:113-24.

21.Ausubel FM, Brent R, Kingston RE, Moore DD, Seidman JG, Struhl K. Current Protocols in Molecular Biology. John Wiley \& Sons, 1988; p2.4:1-2

22.Nazarian S, Gargari SL, Rasooli I, Alerasol M, Bagheri S, Alipoor SD. Prevalent phenotypic and genotypic profile of enterotoxigenic Escherichia coli among Iranian children. Jpn J Infect Dis. 2014;67(2):78-85. 
23.De SN, Chatterje DN. An experimental study of the mechanism of action of Vibrio cholerae on the intestinal mucous membrane. Bull. World Health Organ. 2010 Mar 1;88(3):239-41. 24.Khalesi R NS, Amani J, Ehsani Z, Mansori M, Moazeni SM, et al. Cloning, expression and purification of Escherichia coli heat-labile B subunit as a component of vaccine candidate. Iran chem soci. 2009;15(8):1765-1774

25. Khalesi R, Nazarian S, Ehsaei Z, Mansouri M, Amani J, Salimian J, et al.

Optimization of gene expression and purification of enterotoxigenic Escherichia coli recombinant (2010): 141-147

LTB protein and antibody production against it. Kowsar Medical Journal. 2010;15(3):141-7. YV. 26. Anosova N, Chabot S, Shreedhar V, Borawski J, Dickinson B, Neutra M. Cholera toxin, E. coli heat-labile toxin, and non-toxic derivatives induce dendritic cell migration into the follicleassociated epithelium of Peyer's patches. Mucosal immunol. 2008;1(1):59-67.

27. Moravec T, Schmidt MA, Herman EM, Woodford-Thomas T. Production of Escherichia coli heat labile toxin (LT) B subunit in soybean seed and analysis of its immunogenicity as an oral vaccine. Vaccine. 2007 Feb 19;25(9):1647-57.

28. Saadati M, Salimyan J, Ebrahimi F, Bahmani M, Gandomi A. Evaluation of antibody Y (IgY) raised against botulinum neurotoxin type $\mathrm{A}$ in an animal model. $\mathrm{J}$ Med Sci. 2003;108(2):129-40.

29.Akita E, Li-Chan E, Nakai S .Neutralization of enterotoxigenic escherichia coli heat-labile toxin by chicken egg yolk immunoglobulin $\mathrm{Y}$ and its antigen-binding fragments. Food agric immunol. 1998;10(2):161-72.

30.Arasteh N, Aminirissehei A-H, Yousif A, Albright L, Durance T. Passive immunization of rainbow trout (Oncorhynchus mykiss) with chicken egg yolk immunoglobulins (IgY). Aquaculture. 2004;231(1-4):23-36.

31.Shin J-H, Nam S-W, Kim J-T, Yoon J-B, Bang W-G, Roe I-H. Identification of immunodominant Helicobacter pylori proteins with reactivity to $\mathrm{H}$. pylori-specific egg-yolk immunoglobulin. J. Med microbiol. 2003;52(3):217-22.

32.Malekshahi ZV, Gargari SLM, Rasooli I, Ebrahimizadeh W. Treatment of Helicobacter pylori infection in mice with oral administration of egg yolk-driven anti-UreC immunoglobulin. Microb Pathog. 2011;51(5):366-72.

33.Copelan E, Bechtel T, Klein J, Klein J, Tutschka P, Kapoor N, et al. Controlled trial of orally administered immunoglobulin following bone marrow transplantation. Bone marrow transplant. 1994;13(1):87-91.

34.Bellingeri RV, Busso L, Alustiza FE, Picco NY, Molinero DP, Grosso MC, et al. Characterization of egg yolk immunoglobulin (IgY) against enterotoxigenic Escherichia coli and evaluation of its effects on bovine intestinal cells. 2013.

35.Larsson A, Carlander D. Oral immunotherapy with yolk antibodies to prevent infections in humans and animals. Ups. J. Med. Sci. 2003;108(2):129-40.

36.Liou J, Shiau J, Tai C, Chen L. Production of egg yolk immunoglobulin against Escherichia coli from white Leghorn and Lohmann chickens. J Anim Vet Adv. 2011;10(18):2349-56.

37.Kovacs-Nolan J, Mine Y. Egg yolk antibodies for passive immunity. Annu Rev food Sci Technol. 2012;10(3):163-82.

38. Pauly D, Chacana PA, Calzado EG, Brembs B, Schade R. IgY technology: extraction of chicken antibodies from egg yolk by polyethylene glycol (PEG) precipitation. JoVE (Journal of Visualized Experiments). 2011(51): 30-84.

39. Wen J, Zhao S, He D, Yang Y, Li Y, Zhu S. Preparation and characterization of egg yolk immunoglobulin Y specific to influenza B virus. Antiviral res. 2012;93(1):154-9. 
40. You J, Xu Y, Li H, Wang L, Wu F, Xu F,et al. Chicken egg yolk immunoglobulin (I g Y) developed against fusion protein LTB-ST a-ST b neutralizes the toxicity of E scherichia coli heat-stable enterotoxins. J applied microbiol. 2014;117(2):320-8. 